\title{
Estudo clínico da eficácia da criocirurgia no tratamento de neoplasias de pele e/ou partes moles de cães e gatos
}

Dissertação apresentada ao Programa de Pósgraduação em Cirurgia Veterinária da Faculdade de Medicina Veterinária e Zootecnia da Universidade de São Paulo para obtenção do título de Mestre em Medicina Veterinária

Departamento:

Cirurgia

Área de concentração:

Cirurgia

Orientador:

$\operatorname{Prof}^{\mathrm{a}} \operatorname{Dr}^{\mathrm{a}}$ Júlia Maria Matera

São Paulo 
Autorizo a reprodução parcial ou total desta obra, para fins acadêmicos, desde que citada a fonte.

DADOS INTERNACIONAIS DE CATALOGAÇÃO-NA-PUBLICAÇÃO

(Biblioteca da Faculdade de Medicina Veterinária e Zootecnia da Universidade de São Paulo)

\section{T.1412 Queiroz, Genilson Fernandes de}

FMVZ Estudo clínico da eficácia da criocirurgia no tratamento de neoplasias de pele e/ou partes moles de cães e gatos / Genilson Fernandes de Queiroz. - São Paulo : G. F. Queiroz, 2004.

95 f. : il.

Dissertação (mestrado) - Universidade de São Paulo. Faculdade de Medicina Veterinária e Zootecnia. Departamento de Cirurgia, 2004.

Programa de Pós-graduação: Cirurgia.

Área de concentração: Cirurgia.

Orientador: Profa. Dra. Júlia Maria Matera.

1. Crioterapia. 2. Criocirurgia. 3. Neoplasias. 4. Cães. 5. Gatos. I. Título. 


\section{UNIVERSIDADE DE SÃO PAULO Faculdade de Medicina Veterinária e Zootecnia \\ Cidade Universitária "Armando de Salles Oliveira" \\ Comissão Bioética \\ CERTIFICADO}

Certificamos que o Projeto intitulado “Es da efetividade da criocirurgia no tratamento de neoplasias cuti e/ou de partes moles de cães e gatos", Protocolo $n^{\circ}$ 202/2002, : responsabilidade da Prof ${ }^{a}$ Dr $^{a}$ Júlia Maria Matera, está de acordo os princípios éticos de experimentação animal da Comissão de Bic da Faculdade de Medicina Veterinária e Zootecnia da Universidaı São Paulo e foi aprovado pela referida Comissão, em sessã 25/09/2002.

(We certify that the Research "Effectiveness of cryosurger treatment of skin and soft tissue neoplasie in dogs and cats" prc number 202/2002, under the responsability of Prof ${ }^{a}$ Dr $^{\mathrm{a}}$ Júlia I Matera, agree with Ethical Principles in Animal Research adopt Bioethic Commision of the Faculty of Veterinary Medicine Zootechny of University of São Paulo and was approve 09/25/2002 meeting.

São Paulo, 26 de setembro de 2002

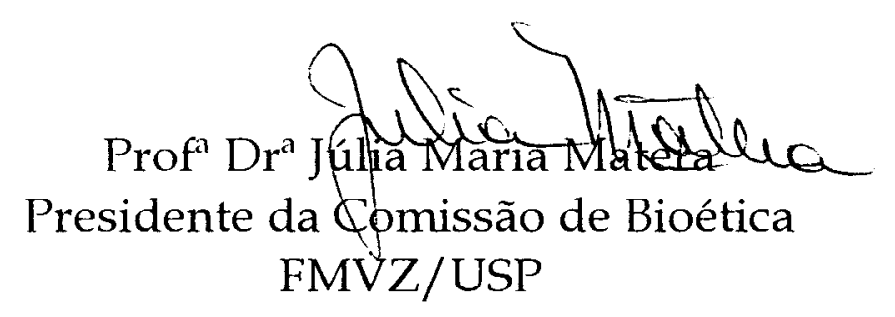

Av. Prof. Orlando Marques de Paiva, 87 - 05508-900 - Cid. Univ. "Armando de Salles Oliv Fone/Fax: (011) 3032-2224/3091-7671/3091-7676 


\section{FOLHA DE AVALIAÇÃO}

Nome: QUEIROZ, Genilson Fernandes de

Título: Estudo clínico da eficácia da criocirurgia no tratamento de neoplasias de pele e/ou partes moles de cães e gatos

Dissertação apresentada ao Programa de Pósgraduação em Cirurgia Veterinária da Faculdade de Medicina Veterinária e Zootecnia da Universidade de São Paulo para obtenção do título de Mestre em Medicina Veterinária

Data:

Banca Examinadora

Professor Dr.

Instituição:

Assinatura:

Julgamento:

Professor Dr.

Instituição:

Assinatura:

Julgamento:

Professor Dr. Instituição:

Assinatura: Julgamento: 


\section{AGRADECIMENTOS}

A DEUS por ter concedido a graça da minha existência, por me fazer persistente, corajoso e acima de tudo crente de que tudo podemos naquele que confiamos.

Aos meus pais, irmãos e familiares que contribuíram grandemente para que atingisse essa etapa de minha vida.

A prof ${ }^{a}$. Dr. ${ }^{\text {a }}$ Júlia Maria Matera, pela oportunidade, confiança em mim depositada, paciência, competência e profissionalismo compartilhados durante esse período.

A Fundação de Amparo a Pesquisa do Estado de São Paulo, pela concessão da bolsa de mestrado, imprescindível para a o desenvolvimento desse trabalho.

A Valéria Veras de Paula, pelo incentivo, convivência e conhecimentos adquiridos nesse período.

Aos professores Angelo João Stopiglia, Cassio Ricardo Auada Ferrigno, Marco Antonio Gioso e Paulo Sérgio de Moraes Barros pela convivência e aprendizado.

As professoras Denise Tabachi Fantoni, Silvia Renata Gaido Cortopassi, Médico Veterinário Rafael Costa Jorge, pós-graduandos, residentes e estagiários do Serviço de Anestesiologia do HOVET - FMVZ/USP, pela colaboração para o desenvolvimento desse trabalho.

A prof ${ }^{a}$ Dr. ${ }^{a}$ Maria Lúcia Zaidan Dagli, Médica Veterinária Luciana Neves Torres do Serviço de Patologia, aos residentes e pós-graduandos desse Departamento pelo profissionalismo e competência dispensados a oncologia.

As Médicas Veterinárias do Serviço de Cirurgia de Pequenos Animais do HOVET - FMVZ/USP, Andressa Gianotti Campos, Patrícia Ferreira de Castro, Sandra 
Aparecida Rosner, Tatiana Soares da Silva e Viviane Sanches Galeazzi, pela colaboração, pelas experiências trocadas, pela convivência.

Aos enfermeiros do Serviço de Cirurgia Serviço de Cirurgia de Pequenos Animais do HOVET - FMVZ/USP, Cledson Lelis dos Santos, Jesus dos Anjos Vieira, Maurício Pavão, Otávio Rodrigues dos Santos pela colaboração, competência e dedicação ao trabalho.

Ao secretário do Curso de Pós-Graduação - Área de Cirurgia, Belarmino Ney Pereira, pelo esforço, apoio e boa vontade dispensados para resolução dos nossos problemas.

A Médica Veterinária Maria Luiza Franchini, bem como a equipe do laboratório clínico do HOVET - FMVZ/USP pela colaboração na realização dos exames necessários para que o trabalho se desenvolvesse.

Aos colegas de pós-graduação pelas experiências trocadas e pelo companheirismo.

Aos residentes e estagiários do Departamento de Cirurgia que de alguma forma colaboraram para a realização deste trabalho.

A equipe da biblioteca da FMVZ/USP pela presteza.

A todos que diretamente ou indiretamente colaboraram para a realização deste trabalho. 


\section{RESUMO}

QUEIROZ, G. F. Estudo clínico da eficácia da criocirurgia no tratamento de neoplasias de pele e/ou partes moles de cães e gatos. [Clinical study of effectiveness of cryosurgery in the treatment of skin and/or soft tissue neoplasia in dogs and cats] 2004. $95 \mathrm{f}$. Dissertação (Mestrado em Medicina Veterinária) - Faculdade de Medicina Veterinária e Zootecnia, Universidade de São Paulo, São Paulo, 2004.

Com objetivo de avaliar a eficácia da criocirurgia no tratamento de neoplasias de pele e/ou partes moles de cães e gatos, foram utilizados 40 animais, 27 cães e 13 gatos de raças e idades variadas encaminhados ao Serviço de Cirurgia de Pequenos Animais do Hospital Veterinário da Faculdade de Medicina Veterinária e Zootecnia da Universidade de São Paulo. Foram tratadas 57 lesões utilizando-se o nitrogênio líquido por meio da técnica do spray, destas 17 $(29,83 \%)$ foram caracterizadas como neoplasia epitelial benigna, 22 (38,60\%) neoplasia epitelial maligna, $4(7,01 \%)$ neoplasia mesenquimal benigna, $10(17,54 \%)$ neoplasia mesenquimal maligna, $3(5,27 \%)$ não neoplásicos e $1(1,75 \%)$ não caracterizado. Houve remissão total de $49(85,96 \%)$ lesões em $32(80 \%)$ animais. Diante destes resultados pode-se concluir que a criocirurgia foi eficaz no tratamento de tumores de pele e/ou partes moles de cães e gatos.

Palavras-chave: Crioterapia. Criocirurgia. Neoplasias. Cães. Gatos. 


\begin{abstract}
QUEIROZ, G. F. Clinical study of effectiveness of cryosurgery in the treatment of skin and/or soft tissue neoplasia in dogs and cats. [Estudo clínico da eficácia da criocirurgia no tratamento de neoplasias de pele e/ou partes moles de cães e gatos] 2004. 95f. Dissertação (Mestrado em Medicina Veterinária) - Faculdade de Medicina Veterinária e Zootecnia, Universidade de São Paulo, São Paulo, 2004.
\end{abstract}

With the aim to evaluate the effectiveness of cryosurgery in the treatment of skin and soft tissue neoplasias of the dogs and cats it was used 40 animals, 27 dogs and 13 cats of differents ages and breeds referred to the Surgery Service of Small Animals of the Veterinary Hospital of the University of São Paulo. Fifty seven lesions were treated with the spray technique using liquid nitrogen. $17(29,83 \%)$ were benign epithelial lesions, 22 (38,60\%) malignant epithelial lesions, 4 (7,01\%) benign mesenchymal lesions, 10 (17,54\%) malignant mesenchymal lesions, $3(5,27 \%)$ not neoplasia, $1(1,75 \%)$ not characterized. There was total remission of the $49(85,96 \%)$ lesions in $32(80 \%)$ animals. It was concluded that the cryosurgery was effective to treat skin and/or soft tissue tumor of the dogs and cats.

Key words: Criotherapy. Cryosurgery. Neoplasia. Dogs. Cats. 


\section{LISTA DE FIGURAS}

Figura 1 - Animal no 5 - A: Adenoma Sebáceo em focinho; B: 21ํ dia de pósoperatório, cicatriz com área de alopecia

Figura 2 - Animal no 10 - A: Carcinoma Basoescamoso em região tóracolombar; B: 330을 dia de pós-operatório, cicatriz com área de alopecia

Figura 3 - Animal no 12 - A: Tricoblastoma Trabecular em região cefálica B: 60 을 de pós-operatório, cicatriz com área e alopecia

Figura 4 - Animal no 18 - A: Carcinoma de Células Escamosas em região periocular; B: Trans-operatório, área excisada com halo de congelamento; C: 7ํ dia de pós-operatório, presença de crosta de tecido necrótico; D: $300^{\circ}$ dia de pós-operatório, cicatriz com área de alopecia

Figura 5 - Animal no 19 - A: Tumor Benigno de Revestimento de Nervo Periférico em região da coxa; B: Trans-operatório, área excisada submetida ao congelamento; C: 45o dia de pós-operatório, presença de tecido de granulação exuberante; D: 330 dia de pós-operatório, cicatriz com área de alopecia

Figura 6 - Animal no 20 - A: Tumor Maligno de Revestimento de Nervo Periférico em terço distal de radio e ulna; B: Trans-operatório, área excisada submetida ao congelamento; C: 7ํ dia de pós-operatório, presença de tecido necrótico e forte edema em membro; D: $330^{\circ}$ dia de pós-operatório, cicatriz com área de alopecia

Figura 7 - Animal no 29 - A: Melanoma Amelânico em região periocular; B: Trans-operatório área de congelamento; C: 120ำ dia de pósoperatório, cicatriz com área de alopecia

Figura 8 - Animal no 30 - A: Epitelioma Sebáceo adjacente à comissura labial

B: Halo de congelamento durante o trans-operatório

Figura 9 - Animal no 38 - A: Epitelioma Sebáceo em face dorsal da mão; B: Trans-operatório, presença de halo de congelamento 


\section{LISTA DE QUADROS}

Quadro 1 - Resultado epidemiológico, clínico, cito e histológico dos animais submetidos a criocirurgia no período de janeiro de 2003 a maio de 2004 no Serviço de Cirurgia de Pequenos Animais do Hospital Veterinário da Faculdade de Medicina Veterinária e Zootecnia da Universidade de São Paulo. São Paulo, 2004

Quadro 2 - Distribuição dos animais tratados pela criocirurgia quanto ao tempo de acompanhamento e avaliação clínica dos resultados. Serviço de Cirurgia de Pequenos Animais do HOVET - FMVZ/USP (janeiro de 2003 a maio de 2004). São Paulo, 2004 


\section{LISTA DE TABELAS}

Tabela 1 - Freqüência dos cães e gatos submetidos a criocirurgia, quanto a distribuição racial. Serviço de Cirurgia de Pequenos Animais da FMVZ/USP (janeiro de 2003 a maio de 2004). São Paulo, 2004.

Tabela 2 - Freqüência das lesões dos cães e gatos submetidos a criocirurgia quanto a localização. Serviço de Cirurgia de Pequenos Animais da FMVZ/USP (janeiro de 2003 a maio de 2004). São Paulo, 2004.

Tabela 3 - Freqüência dos cães e gatos submetidos a criocirurgia em relação aos tempo de evolução das lesões. Serviço de Cirurgia de Pequenos Animais da FMVZ/USP (janeiro de 2003 a maio de 2004). São Paulo, 2004.

Tabela 4 - Freqüência das lesões dos cães e gatos submetidos a criocirurgia em relação aos diâmetros. Serviço de Cirurgia de Pequenos Animais da FMVZ/USP (janeiro de 2003 a maio de 2004). São Paulo, 2004.

Tabela 5 - Freqüência das formações dos cães e gatos submetidos a criocirurgia, distribuição quanto ao resultado do histopatológico. Serviço de Cirurgia de Pequenos Animais da FMVZ/USP (janeiro de 2003 a maio de 2004). São Paulo, 2004. 


\section{LISTA DE ABREVIATURAS}

\begin{tabular}{ll}
$\mu \mathrm{mm}$ & Micrômetro \\
$\mathrm{cm}$ & Centímetro \\
F & Feminino \\
FMVZ/USP & Faculdade de Medicina Veterinária e zootecnia da Universidade de São Paulo \\
HOVET & Hospital Veterinário \\
Kg & Quilograma \\
M & Masculino \\
mg & Miligrama \\
MPD & Membro pélvico direito \\
MPE & Membro pélvico esquerdo \\
MTD & Membro torácico direito \\
no & Número \\
RP & Remoção Parcial \\
RP/R & Remoção Parcil Com Recidiva \\
RT & Remoção Total \\
RA & Remoção Total Com Recidiva Posterior \\
\hline &
\end{tabular}




\section{LISTA DE SÍMBLOS}

$\begin{array}{ll}= & \text { Igual } \\ { }^{\circ} \mathrm{C} & \text { Grau Celsius } \\ \circ & \text { Grau } \\ > & \text { Maior } \\ \geq & \text { Maior ou igual } \\ + & \text { Mais } \\ < & \text { Menor } \\ \% & \text { Porcentagem } \\ \mathrm{x} & \text { Vezes }\end{array}$


1 INTRODUÇÃ

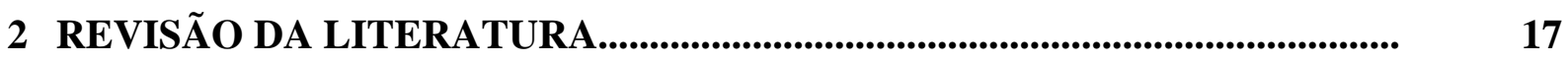

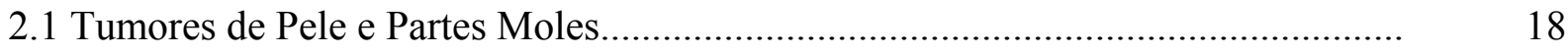

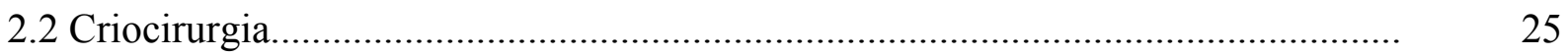

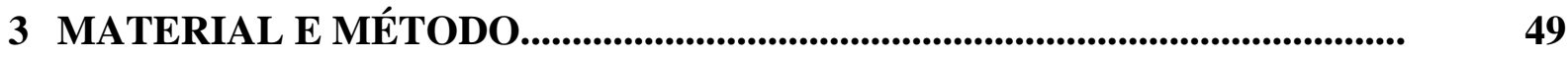

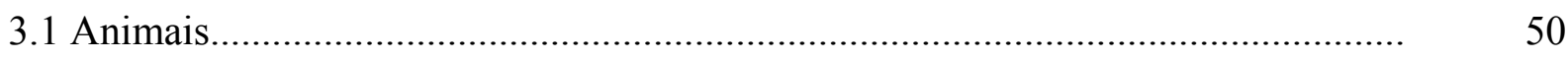

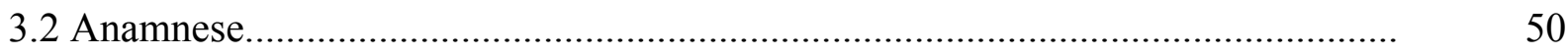

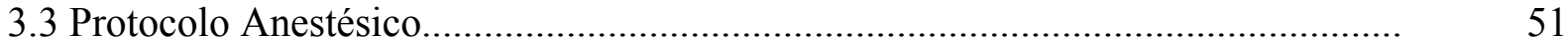

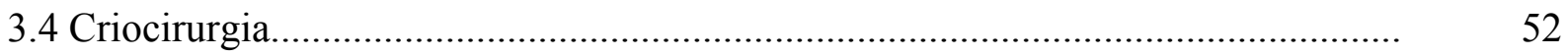

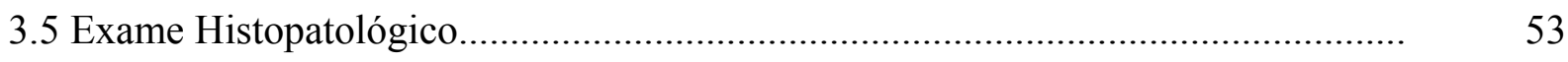

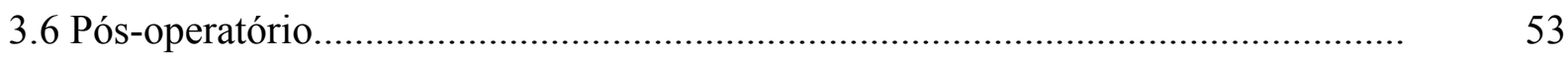

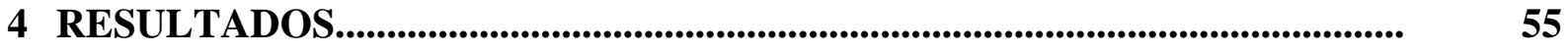

5 DISCUSSÃO

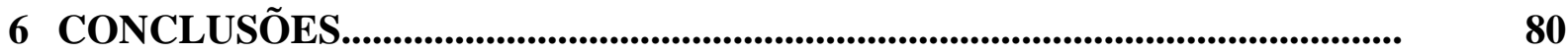

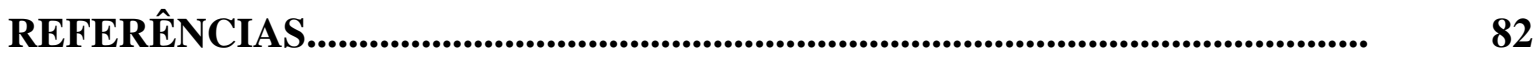

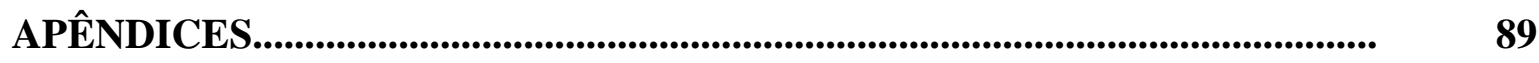


INTRODUÇÃO 


\section{INTRODUÇÃO}

O câncer é uma das principais causas de morte nos animais de companhia nos Estados Unidos (WITHROW, 2001). Os tumores de pele e subcutâneo são os mais comuns que afetam os cães e o segundo mais freqüente nos gatos. Nos cães 20 a 30\% dos tumores são histologicamente malignos comparados com 50 a 65\% nos gatos (VAIL; WITHROW, 2001).

O câncer geralmente é uma doença de animais idosos. Nos últimos 20 anos vários fatores têm contribuído para um aumento da expectativa de vida desses animais, como melhor nutrição, desenvolvimento de vacinas na prevenção de doenças infecciosas, melhores práticas terapêuticas e preventivas, a relação homem-animal e a criação de leis de proteção, a despeito disso, estes apresentam uma maior probabilidade ao desenvolvimento do câncer (GILSON; PAGE, 2000; WITHROW, 2001).

O tratamento racional do câncer requer diagnóstico acurado, o seu estadiamento, o conhecimento do comportamento do tumor em relação ao crescimento local e a tendência a desenvolver metástases regionais e a distância. Há muitas opções de tratamento disponíveis, cada uma com suas vantagens e desvantagens, o médico veterinário deve reconhecer cada modalidade de tratamento e aplicar aquela mais eficaz com base no aspecto e comportamento do tumor (GILSON; PAGE, 2000), no entanto, o grande desafio é conseguir associar a técnica escolhida, com o melhor resultado terapêutico, ao menor custo possível, incluindo o tempo utilizado em ambulatório para que um maior número possível de pacientes possam ser atendidos (LEMOS JÚNIOR, 1999).

A criocirurgia é uma técnica cirúrgica do tipo ablação (FERRIS; HO, 1992) que consiste na destruição de tecidos biológicos através do congelamento (COOPER; DAWBER, 2001). O termo crioterapia é freqüentemente utilizado como sinônimo de 
criocirugia (COOPER; DAWBER, 2001; GAGE, 1992; KUFLIK, 1994), mas o termo crioterapia tem outras conotações e consiste na utilização de baixas temperaturas com muitos propósitos terapêuticos. A criocirurgia é uma forma de crioterapia que utiliza equipamento apropriado para congelamento de tecidos (GAGE, 1992).

A criocirurgia tem ampla utilização na literatura médica, e tem sido investigada como uma técnica alternativa à intervenção cirúrgica no tratamento de muitas doenças. Suas principais vantagens são o potencial de menor invasão e menor morbidade comparada com a intervenção cirúrgica (HOFFMANN; BISCHOF, 2001).

Durante um procedimento cirúrgico convencional as células cancerígenas podem se espalhar e causar metástases através da disseminação por via linfática ou hematógena. A crionecrose dessas células poderá prevenir este problema e deste modo se torna uma possível indicação da criocirugia (HONG; RUBINSKY, 1994).

Face a escassez de dados na literatura veterinária em condições de Brasil e o potencial da criocirurgia de poder ser utilizada como técnica alternativa e de baixo custo à cirurgia convencional, o presente trabalho teve como objetivo avaliar a eficácia da criocirurgia no tratamento de tumores em pele e/ou partes moles de cães e gatos com indicação de congelamento, bem como caracterizar as lesões quanto ao tipo, localização, tempo de evolução e dimensões, observar a evolução dos casos tratados e o eventual aparecimento de complicações e/ou seqüelas. 
REVISÃO DE LITERATURA 


\section{REVISÃO DA LITERATURA}

As informações obtidas na literatura consultada encontram-se dividas como se segue:

2.1 Tumores de pele e/ou partes moles

A pele e o subcutâneo são os locais mais comuns para o desenvolvimento de neoplasias nos cães, representando cerca de 30 a 40 \% de todos os tumores nesta espécie. Nos gatos, $20 \%$ de todos os tumores eles têm origem na pele e subcutâneo, sendo o segundo local mais comum (PETERSON; COUTO, 2000; SCOTT; MILLER; GRIFFIN, 1995; VAIL; WITHROW, 2001).

A incidência estimada de tumores de pele e subcutâneo em cães e gatos nos Estados Unidos é de aproximadamente 450 casos por 100.000 cães e 120 casos por 100.000 gatos (VAIL; WITHROW, 2001). No Reino Unido, de um total de 2.546 formações em cães, os locais mais freqüentes de desenvolvimento foram a pele e/ou tecidos moles, com uma incidência nesses locais de 1437 casos por 100.000 cães por ano. O tipo mais comum na pele foi o histiocitoma, seguido pelo lipoma, adenoma, sarcoma de tecidos moles, mastocitoma e linfossarcoma (DOBSON, 2002).

A neoplasia de pele mais comum nos cães nos Estados Unidos, Austrália e Reino Unido é o mastocitoma, nos gatos nos Estados Unidos é o tumor de células basais, no Reino Unido é o fibrossarcoma (VAIL; WITHROW, 2001). A distribuição quanto à sua origem, os tumores correspondem cerca de 55\% tipo mesenquimal, $40 \%$ epitelial e 5\% melanocítica (SCOTT; MILLER; GRIFFIN, 1995). Alguns tipos específicos apresentam 
predileção por determinadas raças, como o mastocitoma do Boxer e as neoplasias de células basais do Poodle (VAIL; WITHROW, 2001).

As neoplasias cutâneas acometem com maior freqüência os animais idosos, não havendo diferença significativa quanto à distribuição por sexo (VAIL; WITHROW, 2001). As raças de cães que apresentam uma maior incidência ao desenvolvimento de neoplasias de pele são o Boxer, Scottish terrier, Bull mastiff, Basset hound, Weimaraner, Kerry blue terrier e Norwegian elkhound, e de gatos são os Siameses e Persas (SCOTT; MILLER; GRIFFIN, 1995).

A incidência das neoplasias de pele é relatada em diversas áreas geográficas do mundo (NESBITT, 1998), no entanto, essa prevalência varia significativamente de região para região, sendo influenciada por fatores como popularidade das raças, condição social e fatores regionais (GOLDSCHIMIDT; SHOFER, 1992).

Num estudo desenvolvido por Chalita et al. (2001) no município de São Paulo com 213 cães portadores de neoplasias cutâneas e de partes moles, verificou-se que as raças mais acometidas foram os animais sem raça definida (34,5\%), Boxer $(9,9 \%)$, Poodle $(8,4 \%)$, Pastor Alemão (7,0\%) e Cocker Spaniel (5,5\%). Em resultados obtidos por Vasconcellos (2002) de um total de 16 cães estudados observou-se também uma maior frequência de animais sem raça definida (50\%) seguindo-se os cães da raças Boxer (12,5\%) e Rottweiller $(12,5 \%)$.

Os fatores etiológicos específicos da maioria das neoplasias cutâneas são desconhecidos, no entanto, fatores intrínsecos e extrínsecos são implicados na etiologia (NESBITT, 1998). Causas específicas foram comprovadas somente para algumas das neoplasias dos cães. Alguns fatores que contribuem para o desenvolvimento dessas lesões são: vírus (papilomas), radiação solar e lesões térmicas (carcinoma epidermoide), hormônios (adenomas perianais), fatores genéticos (incluindo anormalidades nos oncogenes/genes 
supressores), comprometimento imunológico (PETERSON; COUTO, 2000; VAIL; WITHROW, 2001).

Os tumores são classificados como malignos e benignos, nos cães cerca de 20 a $30 \%$ são histologicamente malignos, comparado com 50 a 65\% nos gatos. O tipo mais comum no cão é o mastocitoma, seguindo-se o carcinoma de células escamosas e melanoma. Nos gatos em ordem crescente temos o carcinoma basocelular, mastocitoma e carcinoma de células escamosas (NESBITT, 1998; VAIL; WITHROW, 2001).

Os tumores benignos de origem epitelial são denominados adenomas, papilomas ou epiteliomas, os malignos são carcinomas, ou adenocarcinoma quando se originam de glândulas ou de ductos (POWERS, 2001).

A classificação da Organização Mundial de Saúde para tumores em animais define tecido mole como aquele tecido de origem não epitelial e extraesquelético, excluindose os tecidos hematopoiéticos, linfóide, glia, porções neuroectodérmicas de nervos periféricos, sistema nervoso autônomo, estruturas paraganglionares, mesoteliais e sinoviais (HENDERSON; BREWER, 1993).

Os sarcomas de tecidos moles são tumores de origem mesenquimal, surgem a partir de componentes do tecido conjuntivo e apresentam comportamento semelhante (DERNELL, 1998; GRAHAM; O’KEEFE, 2000; HENDERSON; BREWER, 1993; NESBITT, 1998). Apresentam origem não epitelial e extraesquelética podendo surgir do tecido fibroso, tecido adiposo, músculo, sinóvia, bem como vasos sangüíneos e linfáticos (GRAHAM; O’KEEFE, 2000). Tumores de origem de tecidos hematopoiético e linfóide são excluídos dessa classificação (MACEWEN, 2001; NESBIT, 1998; WITHROW, 1998).

A classificação histológica dos sarcomas de tecidos moles varia de acordo com o tecido específico de origem, no entanto, alguns tumores apresentam componentes 
indiferenciados dificultando a classificação, sendo denominados de sarcomas indiferenciados (GRAHAM; O’KEEFE, 2000).

Tumores benignos de origem mesenquimal são designados pelo sufixo -oma após o tipo de tecido, por exemplo, fibroma, osteoma, tumores malignos são denominados sarcoma (POWER, 2001).

Em pequenos animais, os tipos histológicos mais freqüentes incluem o tumor maligno de revestimento de nervos periféricos, hemangiopericitoma, fibrossarcoma, histiocitoma fibroso maligno. Nos gatos, a maioria dos sarcomas de tecidos moles é classificada histologicamente como fibrossarcoma, apresentando comportamento biológico similar aos sarcomas dos cães (DERNELL, 1998).

Embora a etiologia dos sarcomas de tecidos moles seja desconhecida, alguns fatores estão associados com o aparecimento desses tumores como: predisposição genética, agentes virais e químicos, radiação solar, implantação de corpos estranhos, trauma e vacinação nos gatos (GRAHAM; O’KEEFE, 2000).

Os sarcomas acometem animais de meia idade a idosos, com tendência para animais de médio a grande porte. Embora não haja predileção por raça ou sexo (DERNELL, 1998), ocorre com uma maior incidência em cães das raças Boxer, Pastor Alemão, São Bernardo, Golden retriever e Basset hounds (GRAHAM; O’KEEFE, 2000). Podem surgir em qualquer local, entretanto, ocorrem com maior prevalência na pele, subcutâneo (MACEWEN, 2001) e músculo do tronco e extremidades (DERNELL, 1998).

Os sarcomas de tecidos moles correspondem de 14 a $17 \%$ dos tumores malignos dos cães e 7 a 9\% dos gatos (DERNELL, 1998), com uma incidência anual nos Estados Unidos de 35 e 17 casos para 100.000 cães e gatos respectivamente (DERNELL, 1998; MACEWEN, 2001), e compreendem mais de 20 subtipos diferentes (GRAHAM; O’KEEFE, 2000; HENDERSON; BREWER, 1993). 
Nos cães, o desenvolvimento de sarcomas tem sido associados com radiação, trauma, corpos estranhos e parasitas (MACEWEN, 2001). Os sarcomas se caracterizam por apresentar um crescimento relativamente lento, são localmente invasivos (DERNELL, 1998; GRAHAM; O’KEEFE, 2000), infiltrando ao longo dos planos e fáscias (DERNELL, 1998; GRAHAM; O’KEEFE, 2000; WITHROW, 1998), podendo invadir veias, artérias, nervos e osso (WITHROW, 1998). Apresentam baixo potencial metastático, as metástases quando ocorrem são na fase mais tardia, sendo que delas $25 \%$ acontecem por via hematógena, os locais mais comumente acometidos são fígado e pulmão (DERNELL, 1998; GRAHAM; O’KEEFE, 2000; NESBITT, 1998).

No exame clínico dos animais portadores de neoplasias de pele e/ou partes moles a história clínica e o exame físico são imprescindíveis (VAIL; WITHROW, 2001). Nos tecidos normais ocorre todo um mecanismo de controle de crescimento, proliferação, diferenciação celular e morte celular. Quando há alterações nesse mecanismo ocorre um desbalanço entre crescimento e morte celular e a partir daí o tumor começa a crescer (MACEWEN; KHANNA; RADINSK, 2001). Portanto, durante a anamnese deve-se inferir da história clínica a evolução da lesão, rapidez de crescimento, alterações na aparência e resposta a terapias prévias. O exame físico consiste na avaliação do tumor em relação as dimensões, localização, consistência, fixação aos tecidos adjacentes e presença de ulceração (VAIL; WITHROW, 2001).

Animais com lesões suspeitas de malignidade e/ou confirmadas devem ser submetidos a exames complementares, como radiografias torácicas, ultra-sonografia abdominal, citologia aspirativa de linfonodos regionais para avaliação de metástases (PETERSON; COUTO, 2000).

Embora a aparência física, localização, e padrão de crescimento do tumor tenham valor preditivo do tipo de neoplasia, é imperativo que se realize o diagnóstico 
citológico e/ou histopatológico para que se planeje procedimento cirúrgico mais adequado e possa estabelecer um prognóstico (VAIL; WITHROW, 2001).

As técnicas de biopsia existentes incluem a punção por agulha fina para exame citológico, agulhas de corte. biópsia com punch, incisional e excisional (WITHROW, 1998). O tamanho e a localização do tumor são fatores determinantes na escolha do tipo de biópsia a ser realizada (VAIL; WITHROW, 2001). Formações pequenas, em local que permite uma excisão com margens adequadas podem ser tratadas através de biópsia excisional (WITHROW, 1998; VAIL; WITHROW, 2001).

A biópsia por agulha fina é comumente utilizada na rotina para o diagnóstico de tumores de pele e/ou partes moles, apresenta-se como um meio de diagnóstico eficiente. Comparando o diagnóstico citológico ao histopatológico, Chalita et al. (2001) e Vasconcellos (2002) observaram uma eficiência de $89 \%$ e 87,5\% respectivamente.

A citologia está indicada para qualquer massa palpável, podendo ser utilizada em cavidades corpóreas com a utilização de agulhas que são guiadas por exames de imagem, freqüentemente a ultra-sonografia (DERNEL, 1998; WITHROW, 1998). Permite diferenciar lesões inflamatórias de neoplásicas (DERNEL, 1998; VAIL; WITHROW, 2001; WITHROW, 1998), distingue tumores de origem epitelial, do tecido conjuntivo (VAIL; WITHROW, 2001) de células redondas como o mastocitoma, melanoma, histiocitoma, linfoma e tumor venéreo transmissível (HENDERSON; BREWER, 1993; PETERSON; COUTO, 2000).

Os sarcomas de tecidos moles são tumores de difícil exfoliação, muito vascularizados, aumentando a quantidade de sangue no material obtido. Esses fatores dificultam o diagnóstico citológico ou pela ausência de material para análise ou por contaminação sangüínea. Tumores muito grandes ou com crescimento rápido podem apresentar necrose central e serem confundidos com abcessos. Sendo assim, diagnósticos 
negativos devem ser interpretados com cautela, procedendo-se a biópsia incisional ou com agulha quando necessário (HENDERSON; BREWER, 1993).

O exame citológico é um procedimento rápido, de baixo custo e bem tolerado pelo animal, não requer anestesia para realização (DERNEL, 1998; WITHROW, 1998). O material é colhido através de uma agulha de 22 a 25G, com ou sem aspiração. A técnica com aspiração envolve a utilização do vácuo criado pela sucção de uma seringa acoplada à agulha. Já a técnica não aspirativa baseia-se na propriedade física da capilaridade, na qual os fluidos tendem a penetrar na luz de uma pequena estrutura tubular (STONE, 1995).

Na biópsia com agulha cortante, obtém-se um fragmento de tecido de 1 a 1,5 centímetros, o qual deve ser fixado em formol e processado para exame histológico. Esta técnica possibilita examinar a arquitetura do tecido e grau de infiltração de vasos sangüíneos e linfáticos (STONE, 1995).

As biópsias com agulha podem ser realizadas em ambulatório, são rápidas e não necessitam de anestesia geral (WITHROW, 1998). Porém este tipo de biópsia apresenta um potencial maior para complicações que a punção por agulha fina, principalmente em lesões muito vascularizadas e sépticas (STONE, 1995).

A principal utilização da biopsia com punch é em massas externas palpáveis, exceto aquelas lesões inflamadas e com tecido necrótico. Pode ser realizada com o paciente sob anestesia local ou sedação (WITHROW, 2001).

A biópsia incisional está indicada quando nem a citologia, nem a colheita com agulha cortante fornece material suficiente. É preferível para lesões ulceradas e necróticas (WITHROW, 2001). Este procedimento requer anestesia geral, expondo o paciente a maiores complicações (STONE, 1995).

O exame histológico da formação após a excisão cirúrgica permite determinar o grau de malignidade e invasão da neoplasia, analisar se as margens de excisão estão livres 
de tumor. As colorações de rotina para análise da morfologia nem sempre permite identificar a neoplasia, sendo necessário o emprego de técnicas de imunoistoquímica para melhor caracterização (VAIL; WITHROW, 2001).

\subsection{Criocirurgia}

No papiro cirúrgico de Edwin Smith por volta de 2500 a.C. já havia relato da aplicação de baixas temperaturas com fins terapêuticos, utilizava-se compressas geladas para tratar fraturas e feridas resultantes de batalha (BELLANGEON, 1999; PODKONJAK, 1982; WHITTAKER, 1984; ZACARIAN, 1994).

Homero, 900 a.C. e Hipócrates, 400 a.C relatam os efeitos benéficos da utilização do frio para o controle de hemorragia e na redução do edema pós-trauma (BELLANGEON，1999; GREINER; LISKA; WITHROW，1975; PODKONJAK，1982; ZACARIAN, 1994).

Por volta de 1661, os médicos de Napoleão recomendavam o congelamento dos membros dos soldados com neve antes de serem amputados, com objetivo anestésico e no controle da hemorragia (PODKONJAK, 1982; WHITTAKER, 1984; ZACARIAN, 1994).

James Arnott, em 1845 faz o primeiro relato científico da utilização de baixas temperaturas, com objetivo de destruição tecidual, utilizando solução salina a $-24^{\circ} \mathrm{C}$ para destruição de tumores de pele, de mama, da cérvix uterina, bem como no tratamento paliativo de pacientes cancerosos terminais com intuito de reduzir a dor e hemorragia local (BAXTER, 1977; COOPER; DAWBER, 2001; GRAHAM, 2001; GREINER; LISKA; WITHROW, 1975; LANE, 1974a; PODKONJAK, 1982; WHITTAKER, 1984; ZACARIAN, 1994). 
Embora tenham obtido efeitos benéficos com a utilização de baixas temperaturas, verificou-se que estas não atingiam profundidade adequada capaz de provocar morte celular, não sendo eficazes no tratamento de tumores, a partir daí surgiu um grande interesse no desenvolvimento do ar liquefeito (COOPER; DAWBER, 2001).

Desse modo, Cailletet em 1877 demonstraram na Academia de Ciência da França que o oxigênio e o monóxido de carbono poderiam ser liquefeitos quando submetidos a altas pressões (BAXTER, 1977; COOPER e DAWBER, 2001; ZACARIAN, 1994).

O conceito de criocirurgia começou a ser amplamente empregado quando Von Linde, em 1895, liquefez o oxigênio (GRAHAM, 2001; ZACARIAN, 1994) e Dewar em 1898 inventou um recipiente a vácuo para estocar oxigênio e nitrogênio líquido (GRAHAM, 2001).

Campbell White, em 1899, foi o primeiro dermatologista a utilizar o ar liquefeito no tratamento de doenças de pele, como verrugas, lesões pré-cancerosas e tumores (COOPER; DAWBER, 2001; GRAHAM, 2001; ZACARIAN, 1994; ZOUBOULIS,1999).

Em 1905, Juliusberg introduziu o termo crioterapia para o tratamento de lesões de pele com utilização do frio. Empregou pela primeira vez o dióxido de carbono liberado em forma de jato (ZOUBOULIS, 1999). Anos depois, Pusey utilizou o dióxido de carbono armazenado em bolsa de couro e comprimido através de finos tubos para congelamento de lesões cutâneas (KUFLIK, 1994).

Estes agentes criogênicos foram utilizados até 1940, a partir daí, foram substituídos pelo nitrogênio líquido devido a sua fácil disponibilidade. O nitrogênio líquido era inicialmente aplicado através de cotonetes para tratar verrugas e queratoses, mas a profundidade destrutiva desta técnica era limitada (COOPER; DAWBER, 2001; KUFLIK, 1994; ZOUBOULIS, 1999). 
Em 1961, Cooper, desenvolveu o primeiro equipamento para utilização do nitrogênio líquido, em um sistema fechado que permitia uma extração rápida e contínua de calor dos tecidos (BAXTER, 1977; BELLANGEON, 1999; COOPER; DAWBER, 2001; GOLDSTEIN; HESS, 1977; KUFKIK, 1994; KUFLIK, 1997; LANE, 1974a), uma década após, Zacarian e Adham utilizavam discos em forma de moeda, mergulhados no nitrogênio líquido antes de serem aplicados sobre a pele no intuito de alcançar maior profundidade de ação (COOPER; DAWBER, 2001; KUFKIK, 1994).

Torre em 1968 desenvolveu a primeira sonda crioterápica para uso dermatológico e Zacarian desenvolveu a primeira unidade portátil de criocirurgia utilizando nitrogênio líquido (COOPER; DAWBER, 2001; GRAHAM, 2001; KUFLIK, 1994). Com esses avanços se conseguiu uma maior profundidade de ação na destruição tecidual, desse modo possibilitou o tratamento de lesões benignas e malignas (KUFLIK, 1994).

A aplicação da criocirurgia em animais se estabeleceu mais recentemente (KRAHWINKEL, 1980). Borthwick e Lane por volta da década de 70 na Inglaterra foram os primeiros autores a descreverem a aplicação prática da criocirurgia veterinária como tratamento de uma variedade de afecções (BELLANGEON, 1999; GOLDSTEIN; HESS, 1976; GOLDSTEIN; HESS, 1977; GREINER; LISKA; WITHROW, 1975; LANE, 1974).

As substâncias criogênicas são gases que ao serem convertidos no estado líquido são capazes de extrair calor dos tecidos. Esta capacidade varia de acordo com a técnica de aplicação e o tipo do criógeno utilizado, pois, diferentes substâncias atingem diferentes temperaturas ou pontos de ebulição (GREINER; LISKA; WITHROW, 1975).

Os agentes criógenos disponíveis podem ser encontrados no estado sólido, líquido e gasoso. Dentre as substâncias criogênicas no estado sólido temos a neve carbônica que atinge temperatura de $-78,5^{\circ} \mathrm{C}$. No estado líquido temos o nitrogênio líquido que atinge temperatura de $-196^{\circ} \mathrm{C}$, no gasoso o gás carbônico e óxido nitroso a $-80^{\circ} \mathrm{C}$ e o freon a $-30^{\circ} \mathrm{C}$. 
A melhor substância criogênica é o nitrogênio líquido, devido suas propriedades físicoquímicas, pois é inerte, inodoro, não inflamável e atinge baixas temperaturas (MAMEDE, 1989).

O nitrogênio líquido é o criógeno de escolha para cirurgias dermatológicas, atinge baixa temperatura e possui maior capacidade de penetração nos tecidos, é mais versátil e destrói grande quantidade de tecidos, é o criógeno recomendado para tratamento de lesões malignas de pele (KUFLIK, 1994; ZOUBOULIS, 1998; ZOUBOULIS, 1999). É dos criógenos o mais acessível em termos de custo e promove um congelamento mais rápido quando comparado com seus congêneres (BAXTER, 1977; BOJRAB, 1978; BRYNE, 1980; GOLDSTEIN; HESS, 1976; GOLDSTEIN; HESS, 1977; GREINER; LISKA; WITHROW, 1975; PODKONJAK, 1982).

O dióxido de carbono, na forma gasosa é incolor, inodoro, inflamável e levemente ácido. É utilizado em instrumentos pressurizados que eliminam o gás por um pequeno orifício, de modo que o congelamento ocorre pelo princípio de Joule-Thomsom, quando um gás passa sob pressão por um pequeno orifício e se expande, a temperatura cai rapidamente (BAXTER, 1977; BRYNE, 1980; GOLDSTEIN; HESS, 1976). Sua baixa capacidade de penetração limita o uso na medicina veterinária apenas para tumores de superfície (BOJRAB, 1978; GOLDSTEIN; HESS, 1976).

O óxido nitroso, gás não inflamável, é o segundo dos gases em termos de facilidade de combustão, é um agente criógeno suficiente para o tratamento de lesões benignas da pele (ZOUBOULIS, 1999). A eficiência da criocirurgia com a utilização do óxido nitroso depende da manutenção da adequada pressão do gás dentro do cilindro (KUFLIK, 1994). O gás é liberado sob alta pressão através de um pequeno orifício e a sua rápida expansão produz baixas temperaturas (BAXTER, 1977; HOLMBERG, 1993; ZOUBOULIS, 1999). 
Os outros agentes criógenos têm uma capacidade de congelamento limitada sendo úteis no tratamento de condições inflamatórias, benignas ou pré-malignas, as quais exigem um menor grau de congelamento (GAGE, 1992; KUFLIK, 1994).

As alterações biológicas que ocorrem como resultado da criocirurgia são causadas devido a redução da temperatura na superfície do tecido e o conseqüente congelamento, ocorrendo uma troca de calor entre o tecido e o gás o qual entra em ebulição (KUFLIK, 1994; ZOUBOULIS, 1999).

A taxa de transferência de calor depende da diferença de temperatura entre os dois agentes, o tecido a ser congelado e o criógeno, como por exemplo, o nitrogênio líquido, 36 e $-196^{\circ} \mathrm{C}$ (KUFLIK, 1997; THAI; SINCLAIR, 1999).

As técnicas de tratamento criocirurgico envolvem dois métodos de transferência de calor, transferência de calor por ebulição e por contato. A transferência de calor por ebulição ocorre quando o nitrogênio entra em contato com a pele, por exemplo, na técnica do spray, o calor perdido da pele é absorvido pelo nitrogênio e este entra em ebulição. A transferência de calor por contato ocorre quando se utiliza sonda metálica congelada no nitrogênio líquido e esta é colocada em contato direto com a pele (KUFLIK, 1994; THAI; SINCLAIR, 1999).

Os aparelhos utilizados na criocirurgia podem ser classificados em sistemas abertos ou fechados (FERRIS; HO, 1992; LEOPARD, 1975). A utilização do sistema fechado consiste no resfriamento da lesão através do contato da sonda crioterápica onde internamente passa o nitrogênio líquido aplicado (FERRIS; HO, 1992). Os sistemas fechados possuem maior controle da área a ser distribuída porém a profundidade alcançada é menor (FERRIS; HO, 1992; LEOPARD, 1975), o metal utilizado nas sondas acaba agindo como uma resistência adicional a transferência de calor. Os sistemas abertos utilizam aplicação direta do nitrogênio sobre a lesão (FERRIS, HO, 1992; LEOPARD, 1975), podendo ser na forma de 
névoa, zaragatoa ou, antigamente, na forma de discos congelantes. Os sistemas abertos possuem pontas com diâmetros variáveis que formam o diâmetro da névoa a ser aplicado (FERRIS; HO, 1992). São mais indicados para lesões proliferativas e invasivas onde se deseja alcançar maior profundidade de destruição (FERRIS; HO, 1992; LEOPARD, 1975).

Cada tipo de equipamento é o mais apropriado para uma determinada lesão, porém, há lesões que podem ser tratadas por mais de um equipamento, em função de preferência pessoal e da experiência do profissional veterinário. Baseia-se no princípio de volatilização do nitrogênio líquido, que quando confinado, em recipiente fechado, tende a buscar uma abertura existente (GOLDESTEIN; HESS, 1976; WITHROW, 1975; WITHROW, 1989).

A escolha do tipo de equipamento, do agente criógeno e da forma de aplicação está relacionada principalmente com o diagnóstico do quadro mórbido, do tipo e da fase evolutiva da lesão, do estado de higidez e do temperamento do paciente e até mesmo em função da estimativa de custo e do tipo de equipamento disponível. Para o estabelecimento do diagnóstico e da escolha da técnica mais adequada é imprescindível que se realize a citologia ou a biópsia, seguida de exame histopatológico (GOURLEY, 1985; LANE, 1974b; MAIA; RIBEIRO, 1997).

A característica básica das técnicas de criocirurgia consiste na desvitalização do tecido neoplásico através do congelamento. A quantidade de tecido a ser congelado deve corresponder à área que seria excisada com uma excisão local conservativa, desse modo, quando o objetivo é a cura, uma margem apropriada do tecido aparentemente normal ao redor da neoplasia deve ser congelada (GAGE, 1992). Há diferentes técnicas que podem ser utilizadas para o tratamento de lesões de pele.

A técnica do contato utiliza sondas metálicas que funcionam pelo princípio da troca de calor (ZOUBOULIS, 1999). A técnica do contato possibilita uma área de necrose 
controlável e previsível, e a pressão da sonda sobre a lesão resulta em uma maior profundidade de congelamento (GAGE, 1990; GAGE, 1992).

Quando o aparelho é ativado e a sonda é colocada em contato com o tecido, uma área do tecido congelado denominada de halo pode ser observado se estendendo radialmente a partir da sonda. A interface entre o halo de congelamento e o tecido não congelado representa uma zona térmica de zero grau. Com um maior tempo de congelamento ocorre uma maior expansão do halo a partir da margem da sonda. A distância entre a margem da sonda e a área térmica de zero grau corresponde a expansão lateral do halo de congelamento. A expansão lateral do halo de congelamento a partir da margem da sonda até a zona térmica de zero grau indica a profundidade de congelamento (FERRIS; HO, 1992; ZOUBOULIS, 1999).

Embora seja variável, a expansão lateral do halo se aproxima a profundidade de congelamento numa relação de 1:1.3 a partir da borda da sonda. O tecido localizado entre a área de congelamento a uma temperatura de $-22^{\circ} \mathrm{C}$ e a sonda é chamado de zona letal. As células localizadas nessa zona sofrem crionecrose, já as células localizadas numa zona térmica de $-22^{\circ} \mathrm{C}$ a $0^{\circ} \mathrm{C}$ geralmente sobrevivem ao congelamento. Esta área é importante porque corresponde a uma zona de recuperação A profundidade máxima de congelamento alcançada é de 20 mm (ZOUBOULIS, 1999).

A desvantagem da técnica do contato que tem sido relatada é a aderência da sonda ao tecido durante o processo de congelamento (GAGE, 1990; GAGE, 1992).

A técnica do spray utiliza um sistema de congelamento aberto que emite um jato de criógeno diretamente na área a ser congelada (KUFLIK, 1994; ZOUBOULIS, 1999). Pode ser utilizada particularmente para lesões planas e lesões com superfícies em relevo (GOLDESTEIN; HESS, 1977; KUFLIK, 1994; ZOUBOULIS, 1999). Ao utilizar a técnica de spray em tumores que apresentem a superfície irregular recomenda-se retirar o tecido em 
excesso para promover um congelamento mais uniforme e eficaz (WITHROW, 1980). Lesões grandes a serem tratadas com uma sessão, o spray pode ser aplicado pelo padrão de pincelamento ou em espiral. O spray é emitido a uma distância de 1 a $2 \mathrm{~cm}$ do local a ser congelado e a um angulo de 90 graus (KUFLIK, 1994; ZOUBOULIS, 1999).

A pressão será inversamente proporcional ao tamanho do orifício de saída. Existem alguns tipos distintos de aparelhos, porém sempre que se utilizam deste princípio, ou seja, o jato de nitrogênio sai por orifícios, de diâmetros pequenos e variados, das diferentes ponteiras. Na dependência do diâmetro das ponteiras, que são padronizadas por cada fabricante, o nitrogênio será expelido numa mistura de líquido-vapor que pode variar na proporção de 15 a 85\% de líquido de 85 a 15\% de vapor, sendo que a maior quantidade de líquido retrata uma maior potência do equipamento (BRYNE, 1980).

A profundidade de congelamento pode ser avaliada em função da expansão lateral do halo de congelamento, e consiste em cerca da metade do raio da superfície congelada. O borrifamento intermitente do nitrogênio liquido é desejável desde que resulte em uma temperatura mais uniforme no halo de gelo e em uma maior profundidade de congelamento. A profundidade de congelamento pode alcançar somente $10 \mathrm{~mm}$, no entanto, não é uma técnica apropriada para lesões volumosas. Para aumentar eficiência, recomenda-se com freqüência a excisão de parte das lesões exofíticas (ZOUBOULIS, 1999).

As desvantagens da técnica do spray consistem na possibilidade de escape do gás dos tecidos durante o tratamento e o risco de insuflação dos tecidos com o gás quando o spray é utilizado em feridas abertas (GAGE, 1990; GAGE, 1992).

As técnicas de congelamento por spray e por contato são limitadas quanto a profundidade de congelamento. Weshahy em 1993 desenvolveu uma técnica de criocirurgia que atinge uma profundidade maior que $20 \mathrm{~mm}$. São introduzidas uma ou mais agulhas em um ponto na pele, e o criógeno borrifado passa através do lumem da agulha atravessa a parte 
mais profunda da lesão e aparece à superfície na borda oposta formando um cilindo de gelo ao redor da parte embutida da agulha dentro do tecido. A distância e a extensão do congelamento podem ser calculadas pelo grau de extensão da bola de gelo formada ao redor dos pontos de contatos entre a superfície da pele e as porções visíveis da agulha. A agulha pode possuir formato em ângulo, curva e moldada em gancho. As principais vantagens da criocirurgia intralesional são o congelamento da lesão inteira independentemente do volume, e a mínima destruição da superfície (ZOUBOULIS, 1999).

O derramamento direto do criógeno consiste na aplicação direta do nitrogênio na lesão ou neoformação. Não é uma técnica comumente utilizada, há risco de disseminação do gás podendo provocar lesões em áreas sadias. Deve ser utilizada com critério e evitar que o nitrogênio líquido se disperse para os tecidos adjacentes (GREINER; LISKA; WITHROW, 1975).

A ação do gelo nos tecidos está relacionada aos efeitos diretos nas células e na estase vascular que se desenvolve após o descongelamento, esta ação depende de diversos fatores: quantidade de calor perdida pelo tecido, da taxa de reaquecimento, da concentração de solutos, do tempo de exposição das células a variação de temperatura e as temperaturas mais baixas no tecido alvo (KUFLIK, 1994).

Durante o congelamento ocorre a formação de cristais de gelo intracelular causando ruptura da célula, após o descongelamento ocorre a destruição completa da célula (GRAHAM, 2001; LEOPARD, 1975; PODKONJAK, 1982). A formação de microêmbolos nos capilares e arteríolas auxilia na destruição do tumor, os grandes vasos permanecem patentes e permitem a neovascularização e cicatrização (GRAHAM, 2001; LANE, 1974a).

A formação do gelo extracelular altera o gradiente osmótico entre as células e o fluido extracelular produzindo um efeito hiperosmolar que extrai água do meio intracelular e induz uma concentração tóxica de eletrólitos, provocando um dano irreversível a célula. O 
aumento da concentração de eletrólitos intracelular produz alterações no pH, nas macromoléculas e na membrana da célula (BOJRAB, 1978; DAWBER, 2002; HOLDEN; MCKELVIE, 1972; KUFLIK, 1997; LANE, 1974a; LEOPARD, 1975; PODKONJAK, 1982; SEIM III, 1980; THAI; SINCLAIR, 1999; ZOUBOULIS, 1999).

O dano irreversível devido a formação do gelo intracelular, é dependente do tempo de congelamento e de uma temperatura mínima atingida. Um congelamento rápido e temperatura baixa, resulta numa maior quantidade de gelo intracelular, o gelo provoca danos nas mitocôndrias e retículo endoplasmático induzindo a uma destruição celular irreversível. Quanto maior o tamanho dos cristais de gelo, maior o dano induzido por eles (DAWBER, 2002; THAI; SINCLAIR, 1999; ZOUBOULIS, 1999).

Quando o congelamento ocorre de forma rápida não ocorre perda de água para o meio extracelular, na tentativa de manter o equilíbrio e desse modo formam-se pequenos cristais intracelulares. Se o descongelamento ocorrer de forma lenta os pequenos cristais intracelulares se convertem em grandes cristais que são muito mais deletérios para a célula. Tal processo denomina-se recristalização (BOJRAB, 1978; DAWBER, 2002; LANE,1974a; SEIM III, 1980; WITHROW, 1975; ZACARIAN, 1994). Porém, se o descongelamento for muito rápido não haverá o processo de recristalização e as células terão grande possibilidade de sobrevivência (GOLDSTEIN; HESS, 1976).

Um congelamento lento leva a formação de grandes cristais de gelo extracelular, mas não provoca tanto dano quanto um congelamento rápido que forma gelo intracelular. Portanto um congelamento rápido no tecido alvo é desejável. Aliado aos efeitos destrutivos dos cristais há também a concentração química dos tecidos. Durante o descongelamento lento ocorre um aumento da concentração de eletrólitos intracelular e junto com a recristalização contribui para o dano celular. Desse modo, o reaquecimento ou descongelamento deve ser processado lentamente (KUFLIK, 1994). 
Os complexos lipoproteicos da membrana celular são ligados por forças instáveis. Durante o congelamento ocorrem mudanças físicas e estes complexos são alterados, resultando em destruição da membrana da célula. Com alteração da integridade da membrana ocorre uma maior permeabilidade aos íons e por sua vez aumento do volume celular com conseqüente ruptura de todas as membranas, como as mitocôndriais, microssomais e nucleares. As alterações eletrolíticas nessas condições têm sido responsáveis pelos danos causados as proteínas e aos sistemas enzimáticos (BOJRAB, 1978; LEOPARD, 1975; SEIM III, 1980; ZOUBOULIS, 1999).

Whittaker (1983) estudando as alterações que ocorria nas estruturas das células imediatamente após descongelamento observou que as mitocôndrias se apresentavam intactas, embora um pouco entumescidas, algumas dilatações em segmentos do retículo endoplasmático. A distribuição de ribossomos, estrutura de tonofilamentos e desmossomos, largura dos espaços intracelulares pareciam normais. Aos 30 minutos de pós-operatório já observava danos ao material mitocondrial, com perda de densidade da matriz, distorção ou perda das cristas, diminuição da densidade do citoplasma, ribossomos amplamente dispersos e alterações nos tonofilamentos. Perda de definição da membrana de células adjacentes era um aspecto constante.

A resposta imediata à ação do congelamento a temperatura de $-20^{\circ} \mathrm{C}$ observada em hamsters foi vasodilatação seguida por vasoconstricção e dentro de 45 minutos completa trombose de microvasos com sinais progressivos precoces de necrose isquêmica do local congelado (ZACARIAN, 1994).

A injúria criogênica provoca estase vascular e anoxia tecidual resultando em necrose isquêmica (ZOUBOULIS, 1999). A estase vascular está restrita ao local de exposição do criógeno e ocorre devido ao aumento da permeabilidade dos vasos resultando em hemoconcentração (SEIM III,1980). 
Em estudos de permeabilidade vascular in vivo em animais, combinando microscopia eletrônica e óptica demonstrou-se a relação entre alterações vasculares e dano celular em condições clínicas. Apesar do dano intracelular ter sido demonstrado dentro de um minuto de descongelamento e haver completa estase na circulação durante o congelamento, a circulação sangüínea volta ao normal em dez minutos. Assim, aparentemente, o dano celular não ocorre devido as alterações vasculares. A partir de uma hora e meia após o congelamento, a passagem de sangue por pequenos vasos se encontra diminuída, isto se torna cada vez mais severo até atingir vasos maiores em 24 horas. Essas alterações ocorrem coincidindo com alterações visíveis na microcirculação regional, incluindo o espaçamento de células endoteliais, aderência de plaquetas e aumento da permeabilidade vascular (LEOPARD, 1975; WHITAKER, 1973).

A formação de trombos ocorre em 65\% dos capilares e 35 à $40 \%$ das arteríolas e vênulas a uma temperatura que varia de 3 à $11^{\circ} \mathrm{C}$, no entanto, a trombose completa dos vasos é detectável a temperatura de $-15^{\circ} \mathrm{C}$ à $-20^{\circ} \mathrm{C}$ após 30 minutos de congelamento (PIMENTEL, 1997; ZOUBLOULIS, 1999).

Aproximadamente duas horas após o congelamento, através de exame microscópico, já se observa edema, danos focais aos capilares, hemorragia e formação de microtrombos. Por volta de 5 à 8 horas se observa necrose focal ou segmentar dos vasos sangüíneos. Clinicamente a gangrena aparece entre 1 à 7 dias, mas somente quando a injúria é severa (ZOUBOULIS, 1999).

Estudos ultra-estruturais em células endoteliais tem mostrado que na primeira hora após o congelamento observam-se ruptura da membrana celular, rarefação e posterior condensação da substância fundamental, tumefação do retículo endoplasmático e das mitocôndrias (ZOUBOULIS, 1999). 
A resposta imunológica seguida a criocirurgia tem sido investigada utilizando modelos experimentais (FAZIO et al., 1982; PODKONJAK, 1982) através da crionecrose de tecidos saudáveis observando-se a produção de auto anticorpos espécie específicos (FAZIO et al., 1982) e foi primeiro sugerida por volta dos anos 60 e 70 quando observou-se a presença de anticorpos circulantes contra tecido prostático e adrenal de humanos e coelhos após congelamento (GOLDSTEIN; HESS, 1976; ZOUBOULIS, 1999). Observações clínicas em caso de sarna demodécica em cães e de sarcóide em eqüinos sugerem estimulação imunológica após a criocirurgia (PODKONJAK, 1982).

Estudos têm demonstrado haver uma resposta imune celular e humoral dirigida contra células transplantadas de tumores após criocirurgia in vitro em roedores com neoplasias induzidas experimentalmente (HOLMBERG, 1993; NEEL III, 1980).

De acordo com Leopard (1975) os possíveis mecanismos envolvidos na resposta imune é que as substâncias antigênicas normalmente encontradas nas células e liberadas quando ocorre destruição celular podem estar associadas a uma resposta antigênica durante a fase de congelamento.

Manobras cirúrgicas capazes de estimular o sistema imunológico, no caso da criocirurgia, possuem papel significativo no tratamento de tumores da cavidade oral. No entanto, existe muita controvérsia em relação aos efeitos imunológicos decorrentes da criocirurgia (FAZIO et al., 1983; FAZIO et al., 1982).

Holden e McKelvic (1972) demonstraram um aumento na atividade linfocitária após a criocirurgia, mas os efeitos clínicos e a especificidade de qualquer célula na resposta auto-imune não foram constatados.

Em pesquisas utilizando a criocirurgia em animais e humanos, em fígado normal e naqueles que apresentavam tumores, observou-se uma intensificação da atividade citotóxica das células nos que apresentavam tumores (ZOUBOULIS, 1999). 
Fazio et al. (1982) estudando os efeitos da criocirurgia em lesões malignas, concluíram que a resposta imunológica é mais notória em pacientes com lesões malignas iniciais, mas em todos os casos, a criocirurgia é capaz de estimular as defesas imunológicas do paciente.

Há evidência crescente de que a necrose, ao invés da apoptose, poderia agir como um adjuvante natural ativando uma resposta imunológica. Partindo desse pressuposto, Gazzaniga et al. (2001) estudaram as alterações inflamatórias após a necrose induzida por criocirurgia em ratos com melanoma humano enxertado. Observaram uma resposta rápida de leucócitos polimorfonucleares ao redor do tumor 24 horas após a criocirurgia com nitrogênio líquido, recrutamento de macrófagos até o terceiro dia, e a resposta de anticorpos foi detectada somente nos animais que tiveram a necrose induzida.

Os tecidos congelam a uma temperatura de $-0,6^{\circ} \mathrm{C}$, no entanto esta temperatura não é letal. Os vários tipos celulares da pele apresentam comportamento distinto em relação à tolerância ao frio. Os melanócitos são as células mais sensíveis ao frio e morrem a temperaturas que variam de $-4^{\circ} \mathrm{C}$ à $-7^{\circ} \mathrm{C}$. As células das glândulas sebáceas e folículos pilosos são sensíveis a temperaturas abaixo de $-20^{\circ} \mathrm{C}$, os queratinócitos apresentam uma resistência considerável, morrem entre $-20^{\circ} \mathrm{C}$ à $-30^{\circ} \mathrm{C}$ e o tecido conjuntivo é o mais resistente, fibroblastos, morrem entre $-30^{\circ} \mathrm{C}$ à $-35^{\circ} \mathrm{C}$ (GRAHAM, 2001; ZOUBOULIS, 1999).

Os criobiologistas têm determinado que a temperatura mínima para produzir crionecrose está entre $-20^{\circ} \mathrm{C}$ à $-30^{\circ} \mathrm{C}$, ocorrendo uma acentuada destruição quando a temperatura está em torno de $-40^{\circ} \mathrm{C}$ à $-60^{\circ} \mathrm{C}(\mathrm{BOJRAB}, 1978)$.

Os excelentes resultados da criocirurgia em lesões de pele deve-se ao fato de que moderado congelamento causa a separação da epiderme da derme e remoção da lesão com rápida epitelização da área. Trabalhos demonstram que o resfriamento da pele de cães a 
$-30^{\circ} \mathrm{C}$ é suficiente para a destruição dos queratinócitos. Quando uma lesão maligna é tratada com criocirurgia os resultados obtidos são bons porque os componentes celulares são mais sensíveis ao frio que os componentes do estroma (KUFLIK, 1994; KUFLIK, 1997).

Muitos cirurgiões utilizaram a temperatura de $-20^{\circ} \mathrm{C}$ como temperatura alvo para o tratamento de tumores malignos, no entanto, estudos mais recentes têm demonstrado que esta temperatura não é adequada, exceto para tumores benignos. No tratamento crioterápico de tumores do tipo carcinoma basocelular e carcinoma de células escamosas, as técnicas atuais requerem temperaturas no tecido alvo em torno de $-50^{\circ} \mathrm{C}$, temperatura na qual ocorre congelamento total da pele (KUFLIK, 1994).

A destruição de células de tumores malignos de pele ocorre quando a temperatura na extremidade da sonda está em torno de $-180^{\circ} \mathrm{C}$ e no tecido alvo em torno de $-50^{\circ} \mathrm{C}$ à $-60^{\circ} \mathrm{C}$ em todas as regiões do tumor, incluindo margens laterais e profundidade, uma criocirurgia ótima para lesões benignas requer temperatura de $-20^{\circ} \mathrm{C}$ à $-25^{\circ} \mathrm{C}$ (ZOUBOULIS, 1999).

Os cirurgiões do Reino Unido recomendam um congelamento contínuo de 30 segundos, já nos Estados Unidos se preconiza congelamento intermitente por 30 à 60 segundos até que sensores térmicos registrem temperatura de $-50^{\circ} \mathrm{C}$ ou se obtenha um halo de congelamento de $5 \mathrm{~mm}$ ao redor do tumor. Alguns autores preferem dois ciclos de congelamento-descongelamento, no entanto, outros autores tem obtido bons resultados com um simples congelamento para tumores com profundidade inferior a 3mm e um tempo de descongelamento de 1 minuto e meio ou mais (GRAHAM, 2001).

O tempo de descongelamento do halo deve ser de pelo menos 1 minuto, no entanto, o descongelamento completo ocorre por volta de 3 a 5 minutos. O segundo tempo de descongelamento deve ser de pelo menos 30 segundos a mais do que o primeiro (GRAHAM, 2001). 
Um congelamento rápido, de 1 minuto ou menos, produz temperatura menor no tumor quando comparado com um congelamento lento de 2 à 3 minutos e deste modo causa a destruição completa de todas as células do tumor (GRAHAM, 2001).

A profundidade do tecido a ser congelado deve ser monitorizada quando da utilização da criocirurgia em tumores malignos de pele. No tratamento de lesões benignas a monitorização da profundidade é opcional. A evolução do congelamento pode ser clinicamente avaliada pela duração do congelamento, do descongelamento da lesão e mensuração da expansão lateral do halo de gelo, quando se utiliza a técnica do contato, ou o raio do halo. Para complementar a estimação clínica, a temperatura nos tecidos pode ser monitorizada por sondas térmicas montadas em agulhas. As sondas térmicas são inseridas dentro da pele de forma que fiquem posicionadas abaixo ou lateral a lesão. Outras técnicas de monitorização são a mensuração da impedância elétrica no tecido congelado e o ultra-som (ZOUBOULIS, 1999).

A destruição celular é diretamente proporcional ao número de ciclos de congelamento-descongelamento. Desse modo durante um procedimento de criocirurgia via de regra deve-se congelar o tecido alvo pelo menos duas vezes (BOJRAB, 1978).

As células cancerígenas são resistentes ao congelamento, portanto devem ser congeladas a temperaturas entre $-40^{\circ} \mathrm{C}$ à $-50^{\circ} \mathrm{C}$ ou abaixo destas temperaturas. Experimentos in vivo e in vitro têm demonstrado que algumas células sobrevivem a temperaturas entre $-70^{\circ} \mathrm{C}$ à $-100^{\circ} \mathrm{C}$ e conseguem se multiplicar em culturas. A capacidade destas células de se multiplicar após exposição a temperaturas de $-60^{\circ} \mathrm{C}$ ou mais despertou a necessidade de maiores cuidados na técnica de criocirurgia. A capacidade de resistência destas células ao congelamento é a razão para a utilização de repetidos ciclos de congelamentodescongelamento (GAGE; BAUST, 2002). 
Os princípios básicos da técnica de criocirurgia incluem um congelamento rápido, um desconglemanto lento e uma imediata repetição do ciclo de congelamentodesconglemanto. O descongelamento deve ser completo antes da repetição do ciclo de congelamento (GAGE, 1992).

Repetidos ciclos de congelamento-descongelamento asseguram o máximo dos efeitos destrutivos em tumores cutâneos. Em estudos com auxílio da microscopia eletrônica em pele normal observou-se que a destruição de todas as estruturas das células ocorria após o segundo ciclo de congelamento-descongelamento (KUFLIK, 1994; THAI; SINCLAIR, 1999; ZOUBOULIS, 1999).

Um duplo ciclo de congelamento-descongelamento é recomendado para todos os tipos de tumores malignos de pele, a menos que estes sejam extremamente superficiais. Tumores benignos ou lesões pré-cancerígenas requerem apenas um ciclo de congelamentodescongelamento (ZACARIAN, 1994).

A criocirurgia teve aplicação clínica substancial por volta da década de 90, sendo utilizada especialmente no tratamento de tumores. Grandes avanços nesta área se deram devido o surgimento de aparelhos de ultra-som intra-operatório, pois estes possibilitam a detecção de tumores viscerais, bem como visualização do processo de congelamento. Aliado a isso, o desenvolvimento de diversificados equipamentos criocirúrgicos expandiu sua aplicação em outras áreas. Especial atenção foi dada ao tratamento criocirúrgico de tumores de próstata, fígado e rins (GAGE; BAUST, 2002 ).

Diversos tipos de tumores em diversas áreas do corpo como pele, osso, ânus, reto, útero e cavidade oral tem sido tratados com criocirurgia. Apesar do grande número de pacientes tratados nestas áreas, não houve grandes avanços nas últimas décadas (GAGE; BAUST, 2002). 
A criocirurgia tem indicação no tratamento de diversas lesões benignas, tumores malignos e pré-malignos de pele. É o método considerado como tratamento de escolha ou tratamento alternativo em diversas afecções de pele. Qualquer área do corpo pode ser tratada, não existe limite de idade. Se os resultados não forem suficientes na primeira sessão, o tratamento pode ser repetido depois de 20 a 30 dias (KUFLIK, 1994; ZOUBOULIS, 1998).

A criocirurgia possibilita o tratamento de tumores recidivantes, lesões próximas ou aderidas a ossos e cartilagens, tumores grandes ou pequenos, múltiplos, como metástase cutânea disseminada de melanoma não operável. Ela é indicada em paciente cirúrgico de alto risco, portador de marca-passo, de coagulopatia, idoso. É um método alternativo para pacientes nos quais outros métodos de tratamento são impraticáveis (KUFLIK, 1994).

Na medicina e medicina veterinária, autores diversos, têm indicado a criocirurgia para o tratamento de uma variedade de neoplasias (ANTHONY, 2000; BELLANGEON, 1999; BOJRAB, 1978; COOPER; DAWBER 2001; GAGE, 1990; GAGE, 1992; GAGE 1997; GAGE; BAUST, 2002; GOLDSTEIN; HESS, 1977; GRAHAM, 1993; GRAHAM, 2001; GREINER; LISKA; WITHROW, 1975; KRAHWINKEL, 1980; KUFLIK, 1994; KUFLIK; LANE, 1974a; LANE, 1974b; LEMOS JÚMIOR, 1999; LEOPARD, 1975; LISKA, 1980; STOCKFLETH; STERRY, 2002; THAI; SINCLAIR, 1999; WITHROW, 1975; YOUNG; SINCLAIR, 1997; ZACARIAN, 1994; ZOUBOULIS, 1998).

Kuflik (1997) utilizou a criocirurgia no tratamento de 54 pacientes humanos com carcinoma basocelular recidivante e obteve uma taxa de cura favorável, com resultados cosméticos excelentes. Apenas dois pacientes tiveram recidiva, um após 3 anos e o outro após sete anos de tratamento. 
Almeida (1997) tratando carcinoma basocelular em região periocular através da técnica de criocirurgia refere que todos os pacientes foram curados clinicamente, tendo em vista que após um período de 5 à 9 anos nenhum paciente apresentava recidiva. Os resultados cosméticos foram satisfatórios, de modo que um ano após o tratamento não se conseguia detectar o local tratado.

Jaramillo-Ayerbe (2000) obteve um taxa de 91,8\% de cura quando utilizou a criocirurgia no tratamento de carcinoma. A técnica foi bem aceita pelo paciente, apresentou resultado cosmético e funcional satisfatório e de baixo custo.

Em um estudo com 395 carcinomas basocelular em 358 pacientes humanos, Bernardeau; Derancourt; Cambie et al. (2000) observaram que após um período de 5 anos a taxa de recidiva foi apenas 9\%, complicações foram raras e obtiveram bons resultados cosméticos.

Menedez (1999) estudando a exeqüibilidade e segurança da utilização da criocirurgia para ablação de sarcomas de tecidos moles em 12 pacientes humanos, foi executada com sucesso em todos os pacientes e que houve $100 \%$ de necrose em 5 tumores. Afirma ser uma técnica exeqüível e segura, embora refira complicações do tipo paralisia em nervo periférico e drenagem serosa.

Em trabalho desenvolvido por Clarke (1991), utilizando a criocirurgia como modalidade de tratamento cirúrgico de carcinoma de células escamosas em felinos, das 163 lesões que foram tratadas com a criocirurgia, ocorreu remissão total em 85 (83\%). As lesões localizadas na pálpebra $(n=23)$ e pina $(n=50)$ resolveram-se com um único tratamento, enquanto que as localizadas em nariz $(\mathrm{n}=90)$ 70\% tiveram remissão após um tratamento, 9\% depois de dois tratamentos e $2 \%$ após três tratamentos. 
Liska (1980), afirma que a criocirurgia é um método eficaz para tratamento de fístulas e adenomas de glândulas perianais em cães, podendo ser executada utilizando-se as técnicas de spray ou sonda.

Utilizando a criocirurgia no tratamento de tumores e fístulas, em cães, Goloubeff; Oliveira (1999) observaram regressão completa em três casos de adenoma hepatóide de glândula perianal, dois casos de fístulas da glândula adanal, quatro casos de tumor venéreo transmissível, um caso de hiperplasia epitelial pseudo carcinomatosa, dois casos de complexo de fístulas glandulares adanal e perianais e um caso de papilomatose oral.

Avaliando a exeqüibilidade, praticabilidade e efetividade da crioterapia em dermatoses de cães, Lucas (1998) obteve uma taxa de involução e cura de 95,3 \% das lesões e resolução do quadro mórbido em $90 \%$ dos caninos, complicações ocorreram em 50\% dos animais.

Em um estudo incluindo a cirurgia, radiação e criocirurgia como métodos de tratamento para carcinomas de células escamosas do plano nasal de 61 felinos, Lana et al. (1997) utilizaram a criocirurgia com nitrogênio líquido em onze casos e destes, 8 (73\%) recidivaram no mesmo local em um tempo médio de 184 dias.

A incidência de complicações após a criocirurgia é baixa. Elas podem resultar de tratamento inapropriado, falha no equipamento, ou inexperiência do operador. As complicações podem ser classificadas como permanentes ou temporárias. As complicações temporárias mais freqüentes incluem hemorragias, edema ou dor durante ou imediatamente após o tratamento. As complicações permanentes incluem retração tecidual, neuropatia, ruptura de tendões, alopecia, ectrópio, hipopigmentação (KUFLIK, 1994; THAI; SINCLAIR, 1999; YOUNG; SINCLAIR, 1997). 
As complicações estão associadas com a duração do tempo de congelamento, profundidade de congelamento, número de ciclos de congelamento-descongelamento empregados (ZOUBOULIS, 1998).

Durante as primeiras 48 horas após o congelamento, o edema e o eritema poderão ocorrer, estas reações são devido a vasodilatação e ao dano provocado no endotélio das arteríolas, veias e capilares (FRETZ; HOLMBERG, 1980).

No homem foram descritas complicações como: hemorragia, dor de cabeça, infecção síncope, reação febril, urticária, insuflação pelo gás nitrogênio e granuloma piogênico. Essas complicações são pouco freqüentes. Lesões em cartilagens, tecido conjuntivo e osso, neuroma traumático são raras de ocorrer porque são estruturas teciduais menos sensíveis ao frio quando comparados com os componentes celulares (ZOUBOULIS, 1994).

A ocorrência de hemorragias pode ser observada em lesões que são biopsiadas antes do congelamento ou em tumores pedunculados que são manipulados durante o congelamento e quebram subseqüentemente, no entanto, uma pressão no local é suficiente para controlá-la (THAI; SINCLAIR, 1999).

Jaramillo-Ayerbe (2000) em experimento utilizando a criocirurgia no tratamento de carcinoma basocelular em pacientes humanos relata não ter notado complicações durante o procedimento. Entretanto, observou dor nas primeiras 12 à 48 horas, edema persistente por 1 à 10 dias e descarga sero-sanguinolenta, foram as complicações mais comuns após a operação.

As contra-indicações podem ser caracterizadas como absolutas e relativas. Há poucas contra-indicações absolutas, como urticária induzida pelo frio, crioglobulinemia, criofibrinogenemia, presença de criofibrinogenio no sangue, tipo anormal de fibrinogenio encontrado raramente no plasma que é precipitado por resfriamento e redissolve-se quando 
aquecido a temperatura ambiente. Dentre as contra-indicações relativas está a doença do colágeno, intolerância ao frio, doença autoimune e despigmentação da pele em pacientes de pele escura (THAI; SINCLAIR, 1999; YOUNG; SINCLAIR, 1997; ZOUBOULIS, 1998).

Marciani e Trodahl (1975) referem como possíveis efeitos adversos da criocirurgia cicatrização lenta, cicatrizes extensas, disfunção estética e funcional importante, persistência de linfoadenopatia. Apesar desses possíveis efeitos eles não devem interferir na escolha da técnica quando a indicação for adequada.

A reação tecidual que ocorre após a criocirurgia é previsível e a cicatrização ocorre por segunda intenção. A morbidade está relacionada com as características e localização da lesão, profundidade de congelamento e resposta do paciente. Uma exsudação local se inicia nas primeiras 24 horas e perdura por diversos dias. Durante essa fase recomenda-se uma lavagem da ferida com água e sabão (GRAHAM, 2001; KUFLIK, 1997).

Em áreas que reagem com forte edema e eritema após a criocirurgia recomenda-se a utilização imediata de cremes a base de esteróides para minimizar estas reações (KUFLIK, 1994; ZOUBOULIS, 1998). Alguns autores recomendam a injeção intramuscular de fosfato de betametasona 30 minutos antes do tratamento, seguido pela prednisona oral durante 3 dias (KUFLIK, 1994).

A cicatrização procede lentamente com formação do tecido de granulação e formação de crosta. Nessa fase os cuidados consistem em lavagem da ferida, aplicação de pomada com antibiótico ou álcool, e se necessário fazer debridamento (KUFLIK, 1997).

Lesões na face, pálpebras, nariz, orelha e pescoço geralmente cicatrizam entre 4 à 6 semanas, enquanto que tumores grandes localizados no tronco e extremidades a cicatrizaçãoocorre por volta de 14 semanas (KUFLIK, 1997). 
A criocirurgia é uma técnica rápida de tratamento quando comparada a excisão cirúrgica, as lesões são congeladas mais rapidamente (GREINER; LISKA; WITHROW, 1975; LANE, 1974a; PODKONJAK, 1982; WITHROW, 2001).

Uma vez que se tenha adquirido experiência com a técnica, a criocirurgia é de fácil aplicação, sendo considerada por alguns cirurgiões como mais fácil que a excisão cirúrgica (WITHROW, 2001).

Apresenta um menor potencial invasividade e menor morbidade (HOFFMANN; BISCHOF, 2001) comparando-se com a excisão que requer uma maior recuperação, ocorrência de dor no local do procedimento cirúrgico, irritação ao longo da linha de sutura, hemorragia durante a operação, infecção e deiscência. Associado a esses fatores o manejo de neoplasias malignas durante o procedimento cirúrgico convencional pode precipitar a disseminação de metástases e não se tem conhecimento de que evoque algum benefício imunológico (LANE, 1974a).

A possibilidade de prevenção de disseminação de tecido neoplásico com um congelamento rápido (HONG; RUBINSKY, 1994; LANE, 1974a) e o desenvolvimento de antígenos para processos neoplásicos oferecem consideráveis vantagens (BOJRAB, 1978; GOLDSTEINS; HESS, 1976; GREINER; LISKA; WITHROW, 1975; HOLDEN; MCKELVIE, 1972; LANE, 1974a).

A criocirurgia é uma técnica segura, e relativamente simples, os procedimentos requerem um menor período de anestesia, evitando dessa forma os riscos da anestesia, principalmente para pacientes idosos (BOJRAB, 1978; GREINER; LISKA; WITHROW, 1975; KUFLIK, 1994). Ela pode ser utilizada em lesões localizadas em áreas da pele onde não há tecido suficiente para aproximar ou em lesões grandes onde não é possível fechamento com sutura (GOLDSTEINS; HESS, 1976; GREINER; LISKA; WITHROW, 1975; PODKONJAK, 1982; SCOTT; MILLER; GRIFFIN, 1995). 
Promove uma analgesia relativa durante e após o tratamento, devido a destruição de terminações nervosas pelo congelamento (HOLDEN; MCKELVIE, 1972; LANE, 1974a; PODKONKAK, 1982).

O custo inicial com a compra do equipamento é elevado, mas o custo dos gases (nitrogênio líquido ou óxido nitroso) utilizados no tratamento geralmente é menos que cinco dólares (WITHROW, 2001), o que torna a técnica de baixo custo (KUFLIK, 1994).

O custo inicial por equipamento varia de 700 a 1000 dólares, no entanto este investimento pode ser compensado com a utilização de anestésicos, material cirúrgico e o tempo de procedimento. Dependendo do número de procedimentos realizados semanalmente a evaporação do nitrogênio líquido é um inconveniente (WITHROW, 2001).

A criocirurgia não é uma cirurgia limpa como a excisão cirúrgica, mas se o proprietário é avisado previamente sobre a ação do congelamento nos tecidos, poucas reclamações surgirão (GREINER; LISKA; WITHROW, 1975; PODKONJAK, 1982; WITHROW, 2001).

Ao contrário de alguns trabalhos relatando uma resposta imunológica sistêmica liberada ou alterando os antígenos matadores de tumor, estudos in vivo não tem sido clinicamente documentado (WITHROW, 2001). 
MATERIAL E MÉTODO 


\section{MATERIAL E MÉTODO}

Para uma melhor compreensão o delineamento da pesquisa foi assim distribuído:

\subsection{Animais}

Foram encaminhados 109 animais ao Serviço de Cirurgia de Pequenos Animais do Hospital Veterinário da Faculdade de Medicina Veterinária e Zootecnia da Universidade de São Paulo, durante o período de janeiro de 2003 a maio de 2004. Destes, 69 foram submetidos à excisão cirúrgica e 40 ao tratamento de criocirurgia associado a excisão ou criocirurgia isolada, sendo 27 cães e 13 gatos. O protocolo utilizado foi aprovado em 26 de setembro de 2002 pela Comissão de Bioética da FMVZ/USP e a inclusão do animal no protocolo, obedeceu critérios relacionados ao tipo de neoplasia, localização, quadro mórbido e autorização do proprietário.

\subsection{Anamnese e Exame Clínico}

A anamnese consistiu em caracterizar as formações quanto ao tempo de evolução, identificar a presença de sinais e/ou sintomas sistêmicos que levasse a suspeita de metástase e/ou síndrome paraneoplásica, bem como, tratamento prévio realizado.

Os animais foram submetidos ao exame físico, radiográfico e/ou ultrassonográfico, eletrocardiograma e exames laboratoriais como hemograma e bioquímica sérica. Os exames laboratoriais foram solicitados de acordo com idade do animal e sintomatologia clínica apresentada. Os exames de imagem foram solicitados naqueles animais 
que ao resultado do exame citológico da neoplasia havia suspeita de tumor maligno com elevado potencial metastático.

Todas as formações foram avaliadas clinicamente em relação as suas dimensões através de mensuração com paquímetro, consistência, superfície, presença ou não de alopecia e ulceração, coloração da pele, comprometimento de tecidos adjacentes e linfonodos regionais.

Todas as formações foram analisadas através de exame citológico antes do procedimento de criocirurgia. O exame citológico consistiu na colheita de material da formação por agulha com calibre 20 X 5,5 através de capilaridade, o material colhido foi depositado em lâminas e realizado esfregaço pela técnica de squash e seco ao ar livre. As lâminas foram encaminhadas ao Laboratório Clínico do Hospital Veterinário da FMVZ/USP, onde foram fixadas com metanol, coradas pelo método de Rosenfeld e analisadas em microscopia óptica de imersão, com aumento de 100X.

\subsection{Protocolo Anestésico}

O protocolo anestésico realizado foi elaborado pelo Serviço de Anestesiologia do Hospital Veterinário da FMVZ/USP, levando-se em consideração as condições clínicas de cada paciente. 


\subsection{Criocirurgia}

Após tricotomia da formação e de áreas adjacentes, o animal foi encaminhado ao centro cirúrgico, realizou-se as técnicas de anti-sepsia com álcool e PVP-Iodo $^{1}$ e isolamento do campo cirúrgico.

As formações em relevo foram excisadas sem margem de segurança e em seguida submetidas ao procedimento de criocirugia do seu leito. Naquelas formações onde havia presença de vasos calibrosos foi realizado ligadura antes do congelamento, com fio de náilon $4-0^{2}$.

A criocirurgia consistiu no congelamento da ferida cirúrgica com nitrogênio líquido através da técnica de spray, utilizando-se o aparelho CRY-AC- $3^{3}$ com ponteiras padronizadas de acordo com o tamanho da área. O nitrogênio era emitido a distância de $1 \mathrm{~cm}$ do tecido a ser congelado e a um ângulo de $90^{\circ}$. O tempo de congelamento variou de 15 à 60 segundos em função do diâmetro da ponteira, tamanho da formação e do quadro mórbido. Nas formações que apresentavam um diâmetro maior que $1 \mathrm{~cm}$, dividiu-se a formação em blocos menores e o congelamento foi realizado em blocos. O tempo de descongelamento foi avaliado através da redução completa do halo de congelamento pela palpação e tato. Todos os pacientes foram submetidos a no mínimo dois ciclos de congelamento-descongelamento, o segundo ciclo de congelamento se procedia após o descongelamento total do primeiro ciclo. A cicatrização ocorreu por segunda intenção.

\footnotetext{
${ }^{1}$ Povidine - Ceras Johnson

${ }^{2}$ Mononylon - Ethicon

${ }^{3}$ CRY-AC-3 - Brymill
} 


\subsection{Exame Histopatológico}

Todas as formação excisadas foram fixadas em formol tamponado salino a 10\%, enviadas ao Serviço de Patologia do Hospital Veterinário da FMVZ/USP, onde foram processadas pelas técnicas rotineiras para inclusão em parafina, cortadas a $6 \mu \mathrm{m}$ e coradas pela hematoxilina-eosina para realização da análise histopatológica.

\subsection{Pós-operatório}

No pós-operatório imediato todos os animais receberam como medicação analgésica e antinflamatória cetoprofeno ${ }^{4}$ pela via intravenosa na dose de $2 \mathrm{mg} / \mathrm{Kg}$ antes do término da anestesia. O controle da dor no pós-operatório foi realizado com carprofeno ${ }^{5}$ na dose de 2,2 mg/Kg por via oral a cada 12 horas durante 5 dias e dipirona ${ }^{6}$ na dose de 25 $\mathrm{mg} / \mathrm{Kg}$ a cada 8 horas por via oral durante 3 a 5 dias. Os proprietarios foram instruídos a administrar tramadol ${ }^{7}$ na dose de $2 \mathrm{mg} / \mathrm{Kg}$ por via oral a cada 8 horas como analgésico de resgate. No pós-operatório prescreveu-se antibioticoterapia a base de Ampicilina ${ }^{8}$ na dose de $22 \mathrm{mg} / \mathrm{Kg}$ a cada 8 horas por via oral por um período inicial de 10 dias, quando necessário este intervalo foi prolongado. As feridas cirúrgicas foram tratadas com água boricada ${ }^{9}$ e com creme a base de neomicina + clostebol $^{10}$ e protegida com compressas de gazes estéreis seguida pela utilização de bandagem com fralda descartável, atadura de crepon trocadas diariamente até completa cicatrização quando necessário. Durante a fase de cicatrização os animais foram acompanhados através de retornos semanais para avaliação do processo

\footnotetext{
${ }^{4}$ Ketofen ${ }^{\circledR} 10 \%$ - Shering Plough Coopers do Brasil Ltda

${ }^{5}$ Rimadyl® - Pfizer

${ }^{6}$ Dipirona ${ }^{\circledR}$ - Geyer Medicamentos S. A.

${ }^{7}$ Tramal ${ }^{\circledR}$ - Searle Monsanto do Brasil Ltda

${ }^{8}$ Ampicilina ${ }^{\circledR}$ - Merck S. A. Industrias Químicas

${ }^{9}$ Genérico

${ }^{10}$ Trofodermin ${ }^{\circledR}$ - Searle Monsanto do Brasil Ltda
} 
cicatricial e/ou possiveis complicações e seqüelas. A alta cirúrgica foi dada quando ocorria a cicatrização total da ferida. 
RESULTADOS 


\section{RESULTADOS}

No período de janeiro de 2003 a maio de 2004 foram operados 87 (79,82\%) cães e 22 (20,18\%) gatos que apresentavam neoplasias de pele e/ou partes moles perfazendo um total de 109 animais. Do total de animais operados 69 (63,3\%) foram submetidos a excisão cirúrgica, e 40 (36,7\%) a excisão cirúrgica associada a criocirurgia e/ou a criocirurgia isoladamente. Dos 40 animais submetidos a criocirurgia 27 (67,5\%) eram da espécie canina e 13 (32,5\%) da espécie felina. Onze animais apresentavam mais de uma formação, contabilizando 57 formações congeladas, sendo 35 lesões nos cães e 22 nos gatos. Os dados de interesse da pesquisa consistem nos 40 animais que foram submetidos ao tratamento de criocirurgia descritos no quadro 1.

Dos 27 cães estudados, 15 (55,56\%) eram machos e 12 (44,44\%) fêmeas, com idades variando entre 4 e 14 anos (média de 10,14 anos). Dentre os 13 gatos, 5 (38,46\%) eram machos e 8 (61,54\%) fêmeas com idade variando entre 1 e 21 anos (média de 9,38 anos). Dentre os cães, constatou-se que 6 (22,23\%) eram sem raça definida (SRD) e 21(77,77\%) eram de raça definida na ordem de prevalência assim distribuída: 18,53\% ( $n=5)$ Cocker Spaniel, 11,11\% (n=3) Boxer, 11,11\% (n=3) Poodle, 7,40\% (n=2) Fox Paulistinha, 7,40\% $(\mathrm{n}=2)$ Pastor Alemão, 3,70\% (n=1) Beagle, 3,70\% (n=1) Bull Terrier, 3,70\% $(\mathrm{n}=1)$ Labrador, 3,70\% (n=1) Malamute do Alaska, 3,70\% (n=1) Old English Sheepdog, 3,70\% (n=1) Pastor Belga. Todos (100\%) os gatos eram SRD. A distribuição racial dos animais estudados encontra-se disposta na tabela 1.

Quanto a distribuição das 57 lesões congeladas, nos cães, 15 (42,86\%) localizavam-se na região da cabeça, 15 (42,86\%) em região de membros, 5 (14,28\%) em região tóraco-lombar; nos gatos todas as 22 (100\%) localizavam-se na região da cabeça. Nessas regiões as formações distribuíam-se em 22, 80\% (n=13) pavilhão auricular, 14,05\% 
$(\mathrm{n}=8)$ face (Figuras 1 e 8), 17,54\% $(\mathrm{n}=10)$ nariz; 7,02\% $(\mathrm{n}=4)$ periocular (Figura 4 e 7); 1,75\% (n=1) lábio; 1,75\% (n=1) mento; 7,02\% (n=4) fêmur (Figura 5); 7,02\% (n=4) rádio e ulna; 5,27\% $(\mathrm{n}=3)$ coxim plantar; 3,51\% $(\mathrm{n}=2)$ metacarpos; $1,75 \%(\mathrm{n}=1)$ tíbia e fíbula; $1,75 \%(\mathrm{n}=1)$ face dorsal da mão (Figura 9); 7,02\% (n=4) tóraco-lombar (Figura 2); 1,75\% (n=1) paraprepucial respectivamente. A tabela 2 apresenta as regiões acometidas bem como a localização de todas as lesões tratadas pela criocirurgia.

Levando-se em consideração ao tempo de evolução das lesões, estas variaram entre 7 e 730 dias. Em 6 (15\%) casos o período de evolução não foi informado pelo proprietário. Na maioria dos casos, 7 (17,5\%), o período de evolução da foi de 60 dias, seguidos por 6 (15\%) casos com 180 dias, 5 (12,5\%) com 365 dias, 4 (10\%) com 120 dias, 3 (7,5\%) com 730 dias, 2 (5\%) com 90 dias, 2 (5\%) com 30 dias, 1 (2,5\%) com 7 dias, 1 (2,5\%) com 10 dias, 1 (2,5\%) com 150 dias, 1 (2,5\%) com 210 dias e 1 (2,5\%) com 240 dias de evolução conforme descrito na tabela 3.

As dimensões das formações em relação ao diâmetro variaram de menos de um a $11 \mathrm{~cm}$, sendo que a maioria, 47 (86,46\%) lesões apresentavam-se com menos de 1 a $3 \mathrm{~cm}$ de diâmetro, dentre as demais, $5(8,77 \%)$ mediam entre 3 à 5 cm, $2(3,51 \%)$ entre 5 à 7 cm, 2 (3,51\%) entre 7 à $9 \mathrm{~cm}$ e $1(1,75 \%)$ acima de $9 \mathrm{~cm}$. A tabela 4 apresenta os valores dos diâmetros das formações com suas freqüências.

Dos 40 animais submetidos ao tratamento de criocirurgia 5 (12,5\%) já haviam sido submetidos a tratamentos prévios sem resultados satisfatórios. Sendo que destes, 2 (5\%) já haviam se submetidos a criocirurgia, 2 (5\%) a excisão cirúrgica e 1 (2,5\%) a quimioterapia.

O diagnóstico citológico foi realizado em 28 (70\%) animais, sendo que 18 (64,28\%) apresentavam formações com características sugestivas de neoplasia maligna, 5 (17,86\%) compatíveis com neoplasia benigna, 5 (17,86\%) com resultado inconclusivo. 
Considerou-se como resultado inconclusivo, as condições onde havia ausência de material suficiente para análise, contaminação sangüínea e/ou casos onde não havia caracterização de malignidade ou benignidade.

Dentre as 57 lesões tratadas, levando-se em consideração a caracterização histopatológica, podemos agrupá-las em formações neoplásicas e não neoplásicas. Assim sendo, evidenciou-se a presença de 3 (5,27\%) formações não neoplásicas e 53 (92,98\%) neoplásicas e 1 (1,75\%) lesão não foi possível caracterizar, provavelmente porque a amostra foi insuficiente para análise. Das neoplasias 15 (28,31\%) tiveram origem em tecidos moles e 40 (71,69\%) epitelial. Os dados referentes as lesões tratadas em relação ao agrupamento encontram-se dispostos na tabela 5.

Em função da caracterização da lesão (plana ou em relevo), localização, quadro mórbido, empregou-se a criocirurgia de forma isolada em 19 (33,33\%) lesões e em associação com a excisão em 38 (66,67\%) lesões.

O tempo de congelamento das lesões foi registrado e variou de 15 a 60 segundos conforme as dimensões da formação e quadro mórbido. O tempo de descongelamento não foi registrado, no entanto, foi avaliado através de palpação digital e observação visual até desaparecimento do halo de gelo. Do total de formações, 25 (43,86\%) foram congeladas por um período de 30 segundos, 16 (28,06\%) durante 60 segundos, 8 $(14,04 \%)$ por 15 segundos e 8 (14,04\%) por 45 segundos. Os dados referentes ao tempo de congelamento está disposto na tabela 6.

Quanto ao número de ciclos de congelamento, 46 (80,7\%) formações, foram submetidas a dois ciclos de congelamento enquanto que 11 (19,3\%) foram submetidas a três ciclos de congelamento.

Acompanhou-se a evolução dos casos tratados através de retornos semanais quando possível ou quinzenais até a cicatrização da lesão. Em 12 (30\%) casos não foi possível 
este acompanhamento porque os proprietários não compareceram nos retornos. Nos 28 (70\%) animais em que se pode acompanhar observou-se que o tempo de cicatrização variou de 15 à 120 dias assim distribuídos: 7 (17,5\%) 30 dias, 7 (17,5\%) 45 dias, 5 (12,5\%) 21 dias, 5 (12,5\%) 60 dias, 2 (5\%) 15 dias, 1 (2,5\%) 90 dias e 1 (2,5\%) 120 dias, conforme descrito na tabela 7.

O procedimento de criocirurgia foi realizado em uma única sessão em 35 $(87,5 \%)$ animais e em duas ou mais sessões em 5 (12,5\%) animais, sendo estes todos felinos.

Para avaliação dos resultados finais estabeleceu-se parâmetros clínicos para análise quantitativa e qualitativa dos dados obtidos. enquadrando-os nas seguintes categorias: remissão total da lesão - RT, remoção parcial da lesão - RP, remoção total da lesão com recidiva posterior - RT/R, e remoção parcial com recidiva da lesão - RP/R e sem alteração SA. Dentre os 40 animais observou-se que 33 (82,5\%) tiveram remissão total de suas lesões no período analisado, 2 (2,5\%) remissão total da lesão com recidiva posterior. O animal de no 7 a recidiva ocorreu 7 meses após o tratamento de criocirurgia. Em 5 (12,5\%) casos não obtivemos resultado a respeito da remissão das lesões pelo não comparecimento dos proprietários aos retornos e impossibilidade de contato por telefone foram os animais de no 6 , 8, 11, 13, 28. O animal de no 17 foi submetido a eutanásia antes da cicatrização da lesão por apresentar caquexia e a necropsia detectou-se presença de formação em baço. Levando em consideração as lesões em si, observamos que 49 (85,96\%) tiveram remissão total, 8 $(14,04 \%)$ lesões foram consideradas como insucesso do tratamento, sendo que em $1(1,75 \%)$ casos devido a recidiva e nos demais por não ter acompanhamento da evolução do caso. Os dados referentes ao tempo de acompanhamento bem como os resultados dos parâmetros clínicos estão descritos no quadro 2.

Quanto as complicações e/ou seqüelas provenientes da ação da criocirurgia podemos observar alopecia em 30 (75\%) animais (Figura 3), edema em 7 (17,5\%) (Figura 6), 
claudicação em 4 (10\%); prurido em 3 (7,5\%), dor em 3 (7,5\%) e hemorragia em apenas 1(2,5\%) animal. A única seqüela encontrada foi um (2,5\%) caso de retração cicatricial com conseqüente obstrução em narina de felino. 

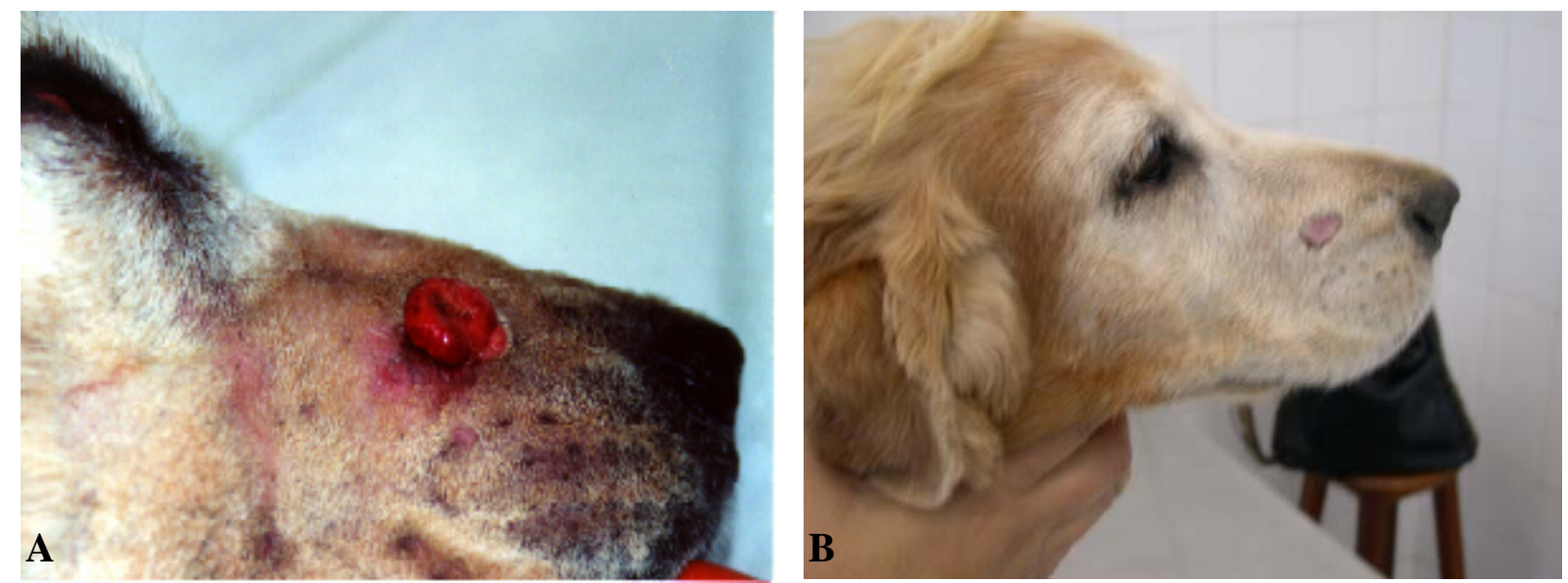

Figura 1 - Animal no 5 - A: Adenoma Sebáceo em focinho; B: 21ำ dia de pós-operatório, cicatriz com área de alopecia
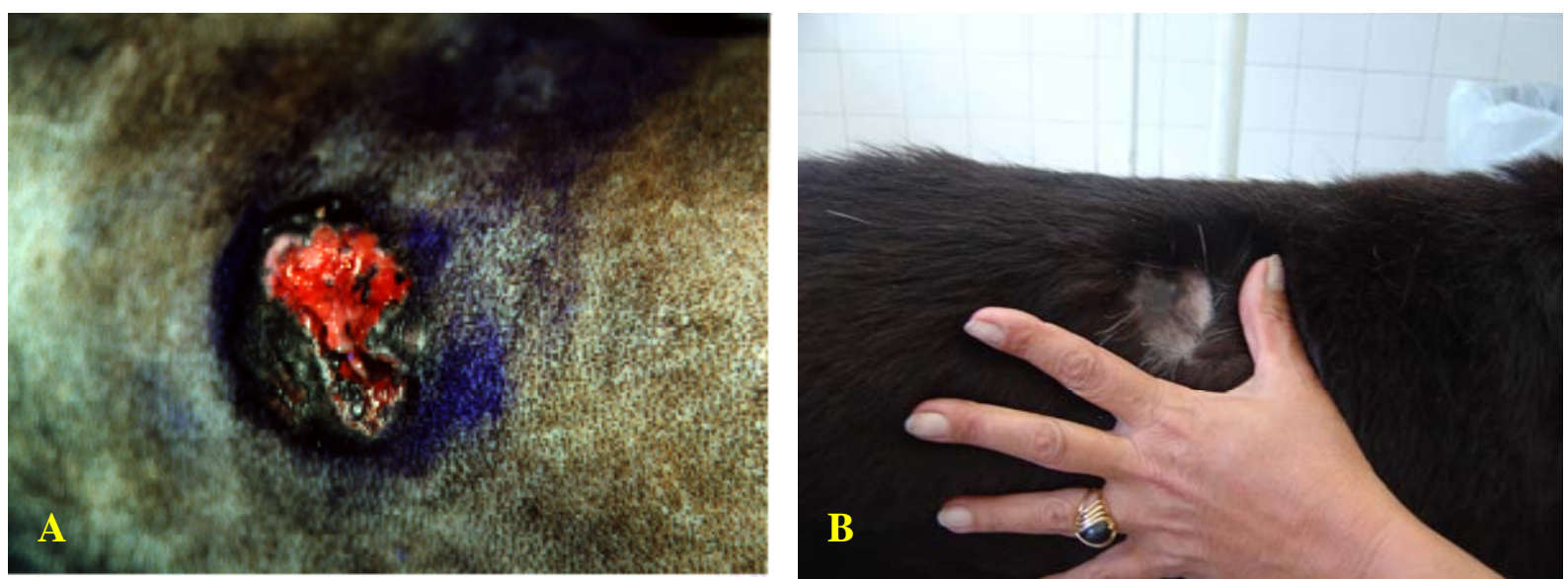

Figura 2 - Animal no 10 - A: Carcinoma Basoescamoso em região tóraco-lombar; B: 330ํ dia de pós-operatório, cicatriz com área de alopecia
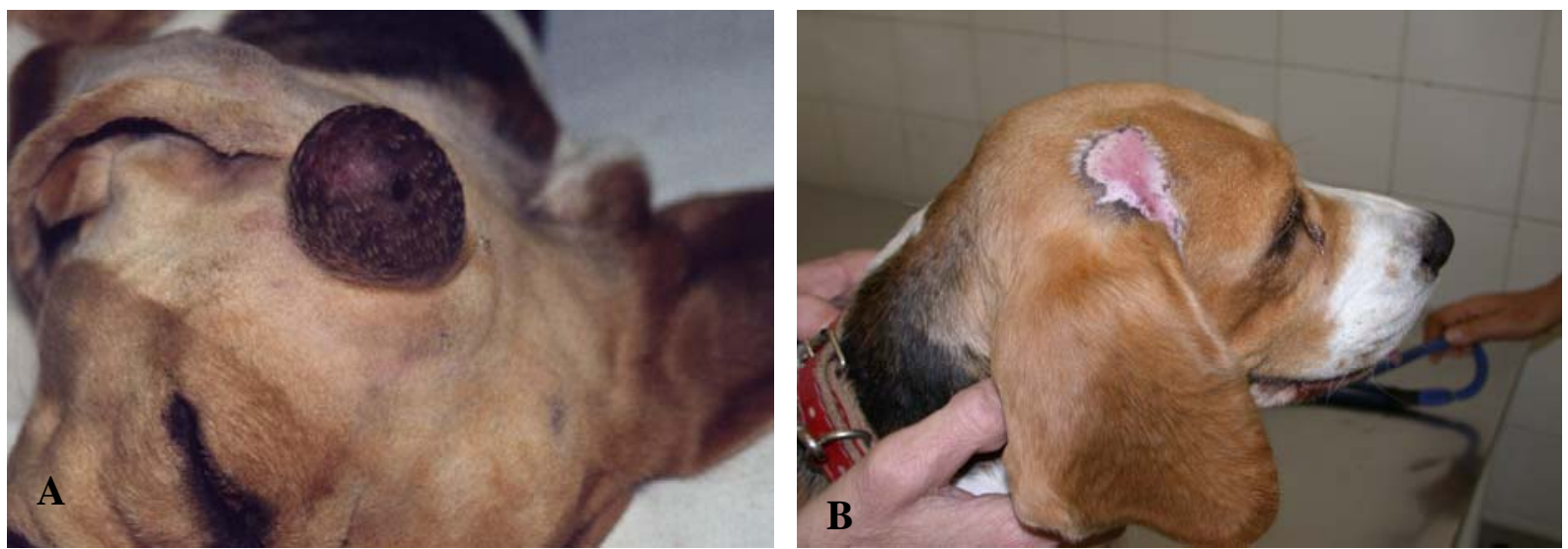

Figura 3 - Animal no 12 - A: Tricoblastoma Trabecular em região cefálica B: 60ํ dia de pósoperatório, cicatriz com área e alopecia 

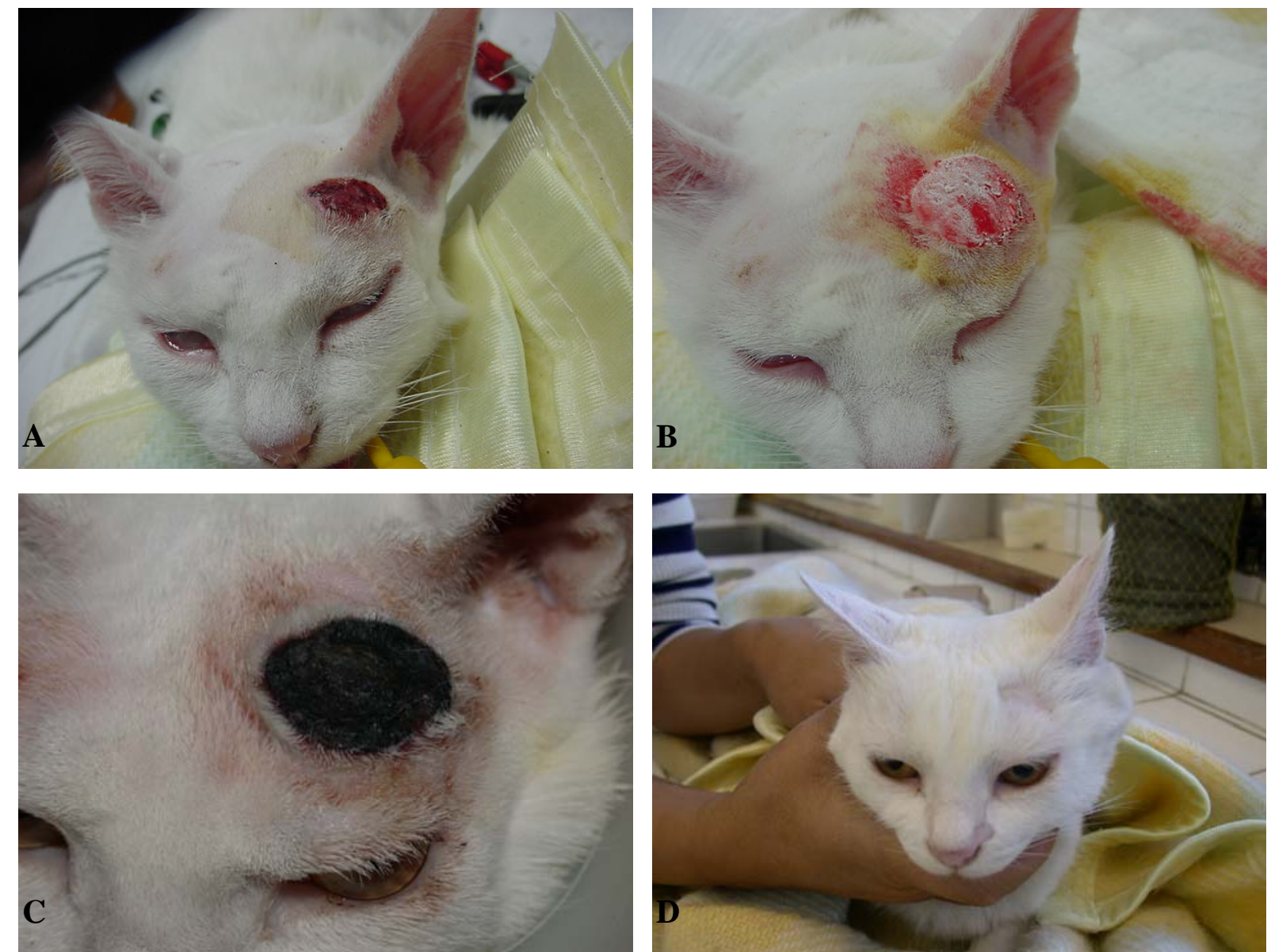

Figura 4 - Animal no 18 - A: Carcinoma de Células Escamosas em região periocular; B: Trans-operatório, área excisada com halo de congelamento; C: 7ํ dia de pós-operatório, presença de crosta de tecido necrótico; D: 300 dia de pós-operatório, cicatriz com área de alopecia 

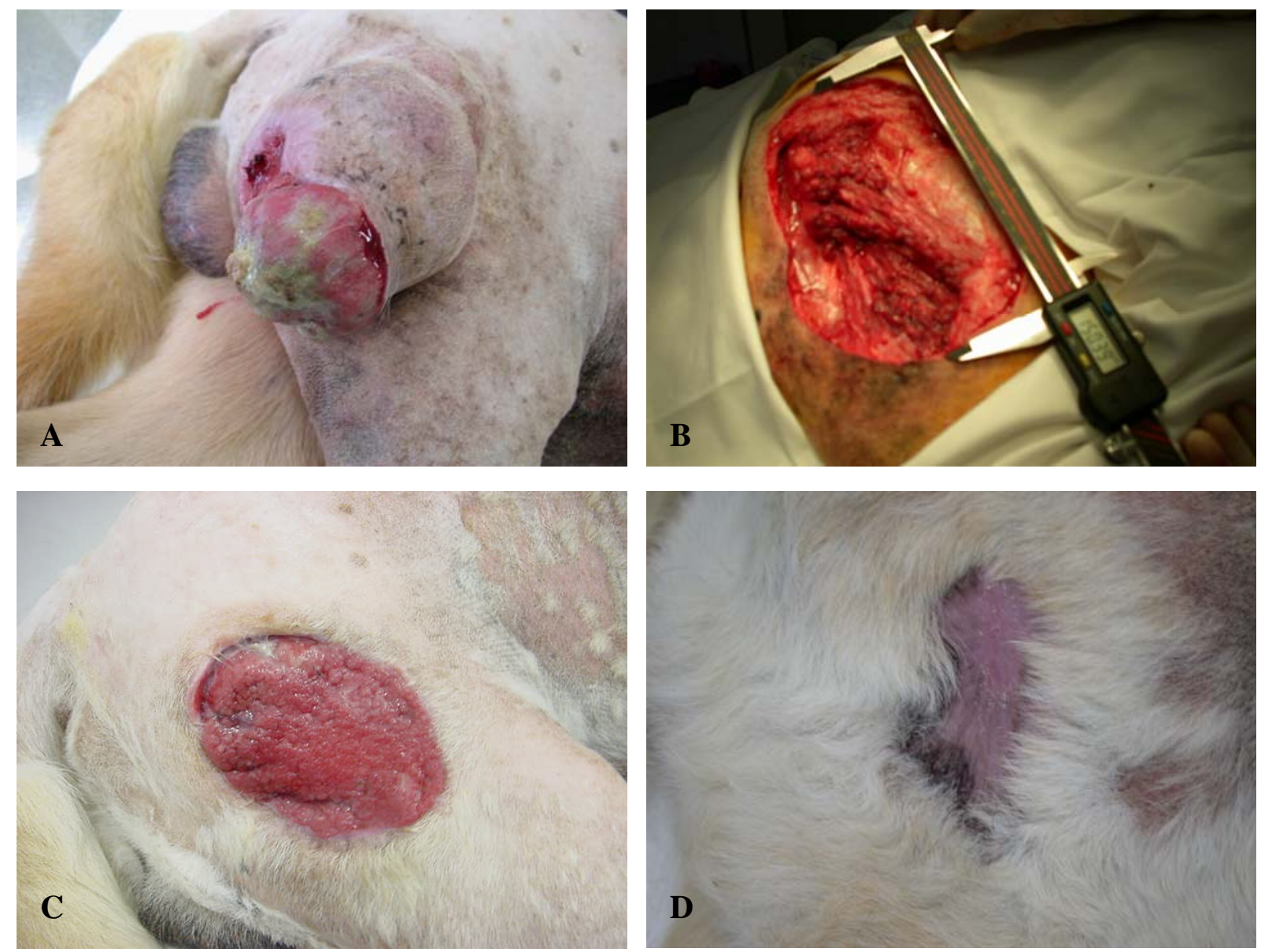

Figura 5 - Animal no 19 - A: Tumor Benigno de Revestimento de Nervo Periférico em região da coxa; B: Trans-operatório, área excisada submetida ao congelamento; C: 45o dia de pósoperatório, presença de tecido de granulação exuberante; D: 330ำ dia de pós-operatório, cicatriz com área de alopecia 

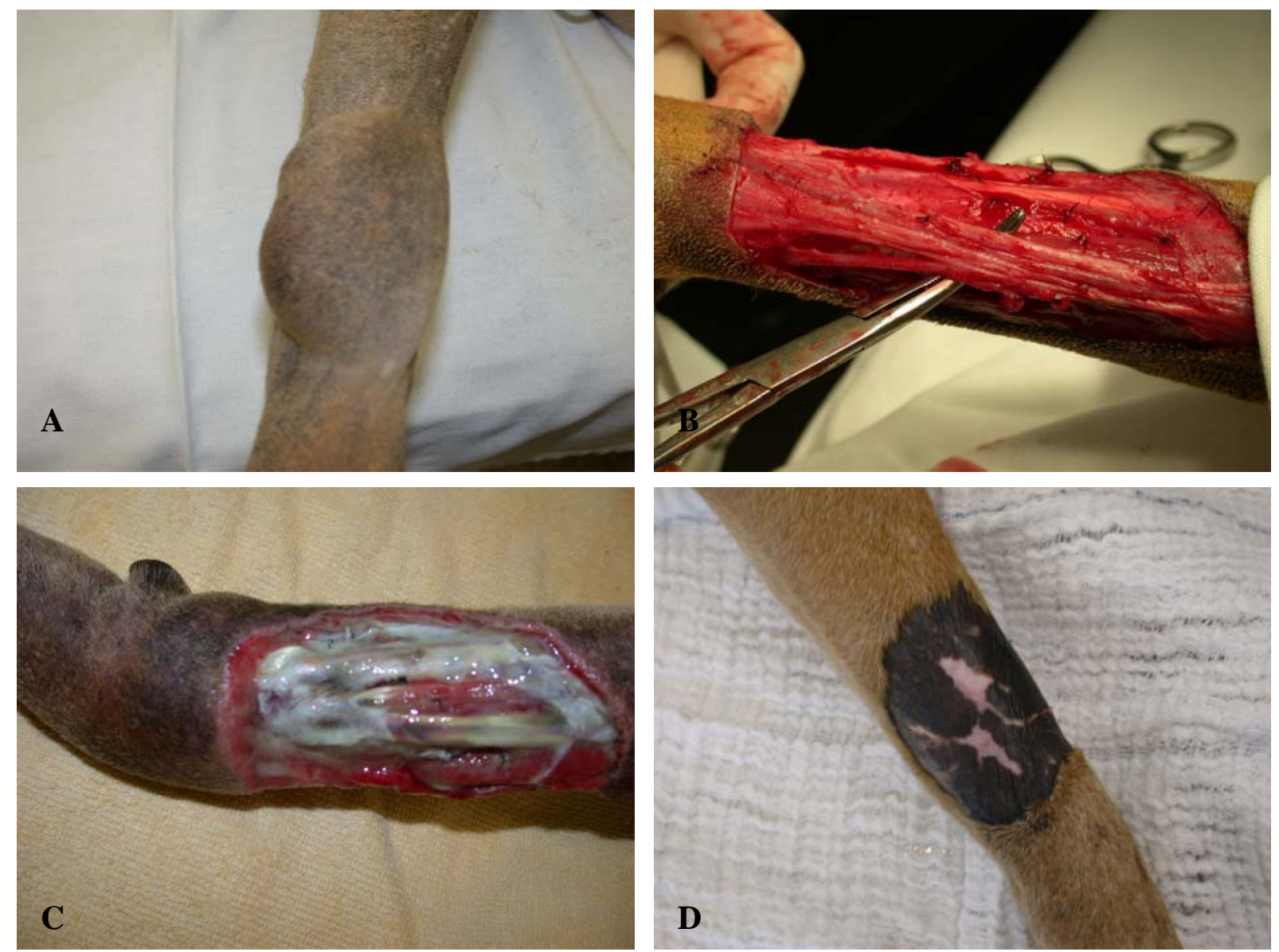

Figura 6 - Animal no 20 - A: Tumor Maligno de Revestimento de Nervo Periférico em terço distal de radio e ulna; B: Trans-operatório, área excisada submetida ao congelamento; C: 7o dia de pós-operatório, presença de tecido necrótico e forte edema em membro; D: 330으 dia de pós-operatório, cicatriz com área de alopecia 

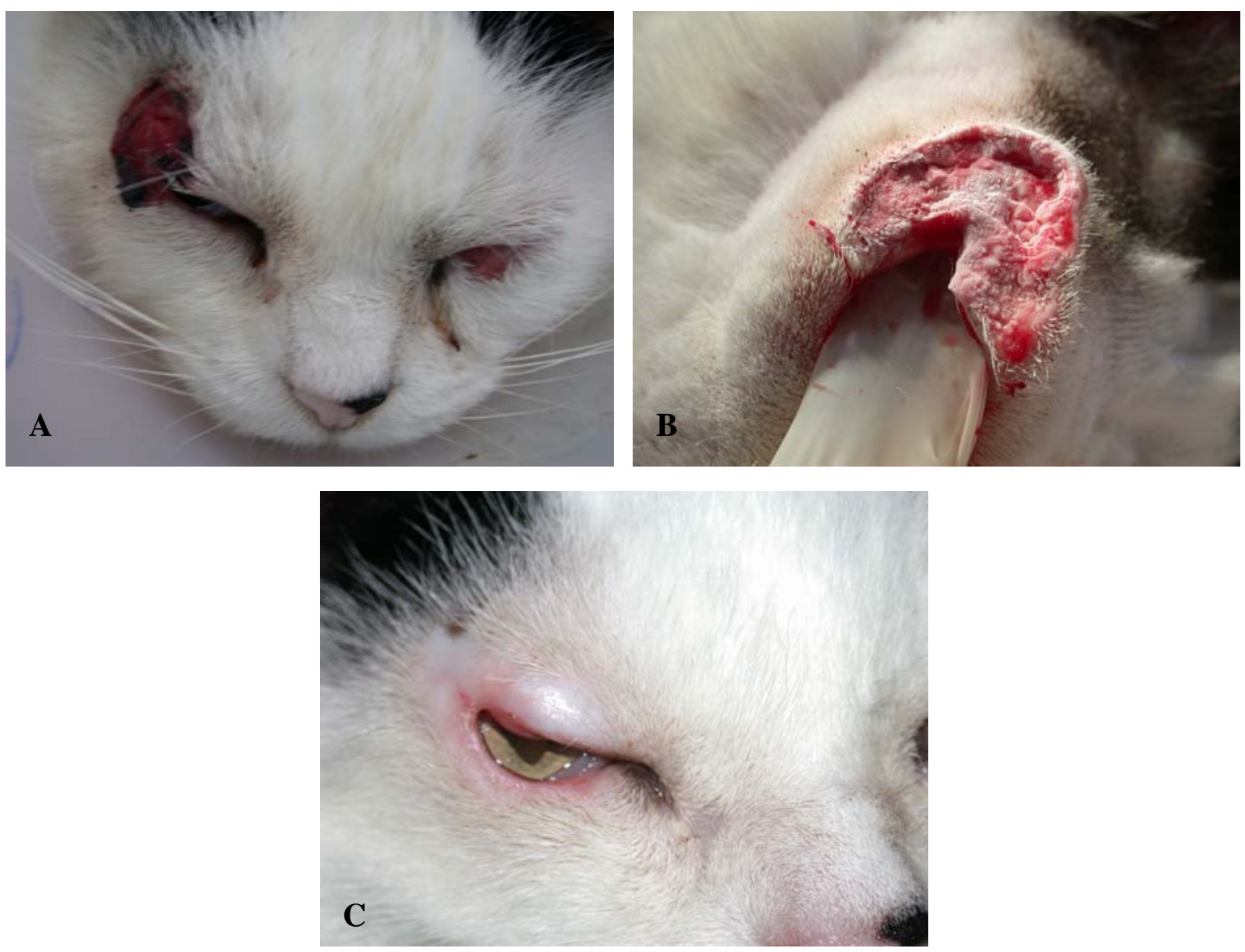

Figura 7 - Animal no 29 - A: Melanoma Amelânico em região periocular; B: Transoperatório área de congelamento; C: 120ํ dia de pós-operatório, cicatriz com área de alopecia
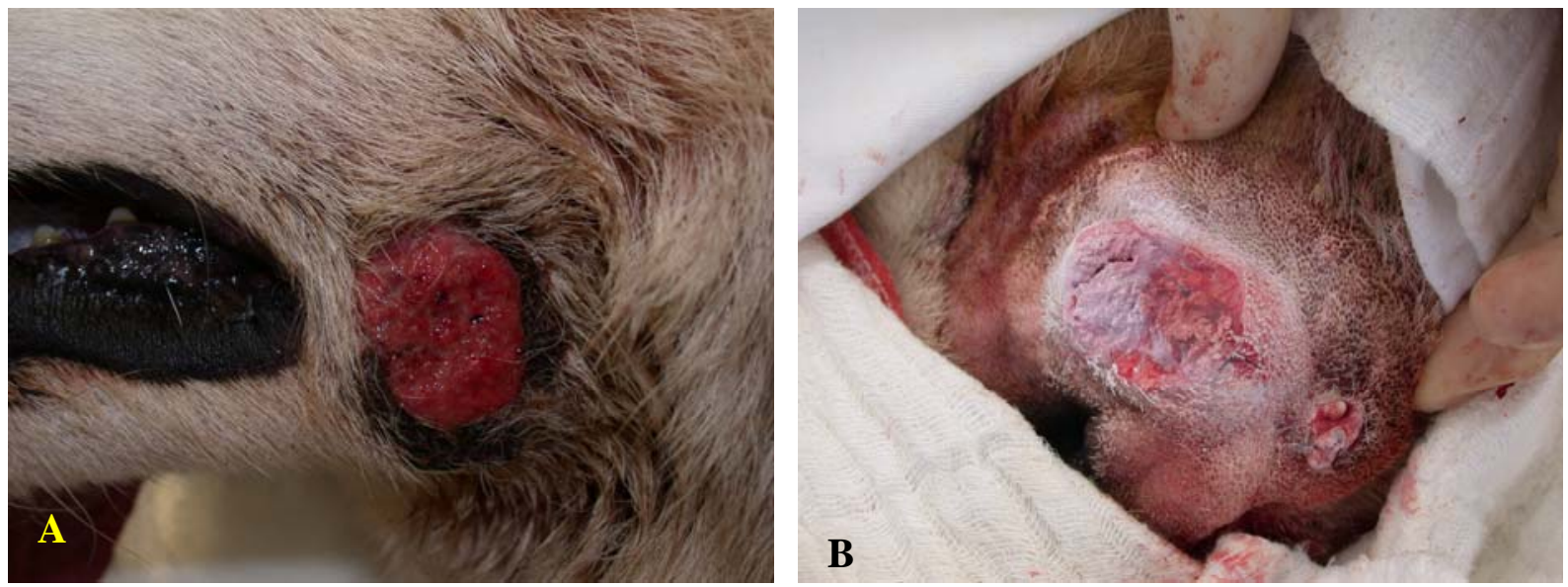

Figura 8 - Animal no 30 - A: Epitelioma Sebáceo adjacente à comissura labial B: Halo de congelamento durante o trans-operatório 

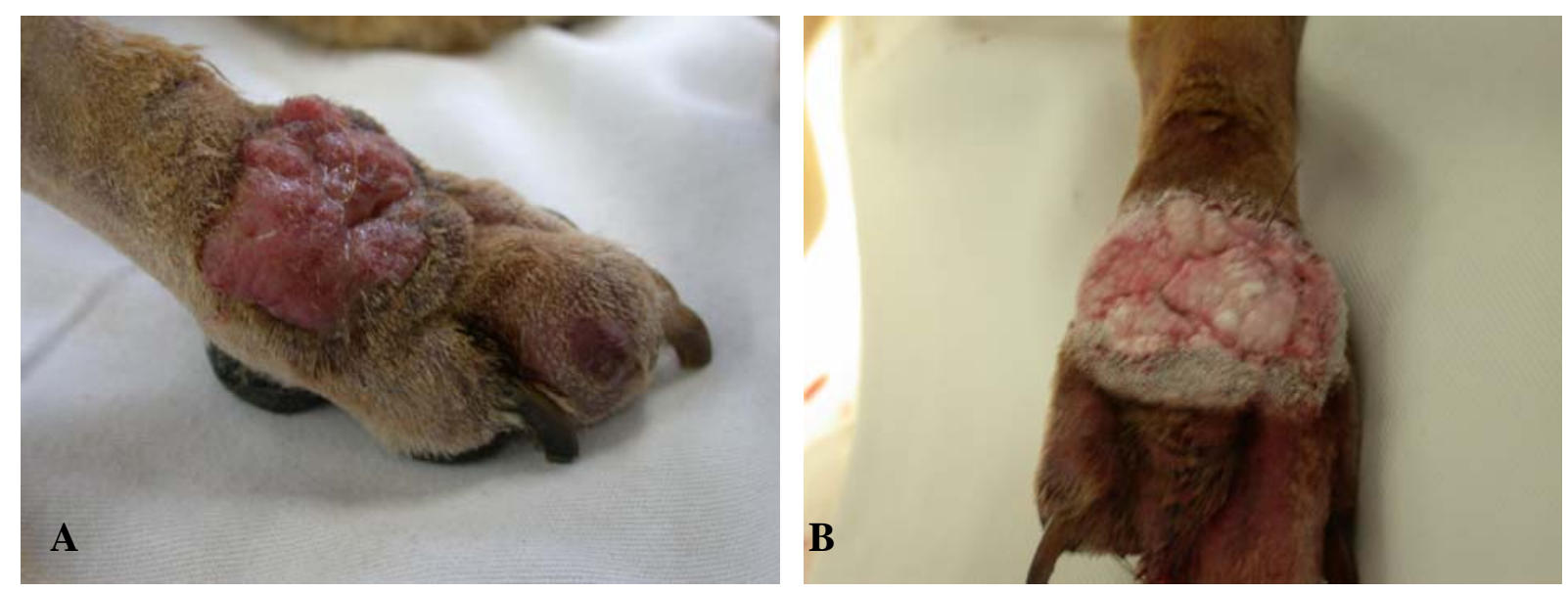

Figura 9 - Animal no 38 - A: Epitelioma Sebáceo em face dorsal da mão; B: Transoperatório, presença de halo de congelamento 
DISCUSSÃO 


\section{DISCUSSÃO}

O grande avanço das pesquisas na medicina de pequenos animais tem contribuído sobremaneira para o desenvolvimento de novas técnicas de manejo, descoberta de novos medicamentos e vacinas, disponibilização de meios de diagnóstico e tratamento. Esses fatores aumentam a expectativa de vida desses animais, em contrapartida estes se tornam mais expostos as ações de fatores ambientais, agentes químicos seja proveniente de resíduos de medicamentos ou de constituintes da alimentação, infecções por vírus e bactérias.

O câncer é uma das principais causas de morte nos animais de companhia nos Estados Unidos (WITHROW, 2001). Os tumores de pele e subcutâneo são os mais comuns que afetam os cães e o segundo mais comuns nos gatos (VAIL; WITHROW, 2001). A distribuição quanto à sua origem, correspondem cerca de 55\% tipo mesenquimal, 40\% epitelial e 5\% melanocítica (SCOTT; MILLER; GRIFFIN, 1995). No Brasil não há dados reais da incidência desses tumores em pequenos animais, no entanto, no nosso estudo observou-se uma freqüência de 71,69\% de origem epitelial e 28,31\% mesenquimal, vale ressaltar que esses dados não são representativos da população de pequenos animais.

O tratamento clássico para remoção de tumores de pele e subcutâneo consiste na ressecção cirúrgica com margem de segurança, no entanto, dependendo do quadro mórbido e da localização da neoplasia esta técnica é impraticável.

Há outras opções de tratamento disponíveis, cada uma com suas vantagens e desvantagens, o médico veterinário deve reconhecer cada modalidade de tratamento e aplicar aquela mais eficaz com base no aspecto e comportamento do tumor (GILSON; PAGE, 2000).

A criocirurgia é uma técnica cirúrgica do tipo ablação (FERRIS; HO, 1992) que consiste na destruição de tecidos biológicos através do congelamento (COOPER; 
DAWBER, 2001). A criocirurgia associada a excisão cirúrgica ou isoladamente foi utilizada em 40 animais portadores de neoplasias de pele e/ou partes moles. Dentre os 40 animais, 27 (67,5\%) eram cães e 13 (32,5\%) eram gatos. O número de animais não é representativo da população de cães e gatos do município de São Paulo, mas diante da amostra podemos constatar que há uma tendência dessas neoplasias acometeram com maior freqüência os caninos. Fato este já comprovado nos Estados Unidos onde a incidência estimada de tumores de pele e subcutâneo em cães e gatos é de aproximadamente 450 casos por 100.000 cães e 120 casos por 100.000 gatos (VAIL; WITHROW, 2001).

Dernell et al. (1998), MacEwen et al. (2001) e Vail e Withrow (2001) relatam não haver predisposição sexual para as neoplasias cutâneas e de partes moles. Dessa mesma forma não se observou diferença quanto ao acometimento nas duas espécies estudadas.

Entre os animais da espécie canina a maioria, 6 (15\%), eram sem raça definida. Comparando esses achados aos resultados obtidos por Chalita et al. (2001) e VasconcelLos (2002) constatamos haver uma predominância dos animais sem raça definida na população canina em relação a esta afecção. Quanto aos felinos, todos eram sem raça definida. A incidência das neoplasias de pele é relatada em diversas áreas geográficas do mundo (NESBITT, 1998), no entanto, essa prevalência pode variar significativamente de região para região, podendo ser influenciada por fatores como popularidade das raças, condição social e fatores regionais (GOLDSCHIMIDT; SHOFER, 1992).

A idade dos caninos portadores de neoplasias de pele e partes moles variou de 4 à 14 anos, média de 10,14 anos, e entre os felinos de 1 à 21 anos, média de 9,38 anos. Esse resultados refletem que animais adultos a idosos são mais predispostos ao desenvolvimento de neoplasias, muito embora possa acometer animais de qualquer faixa etária conforme referido na literatura pesquisada (DERNELL, 1998; VAIL; WITHROW, 2001). 
Diversos autores fazem referência à utilização da criocirurgia no tratamento de tumores de pele em áreas onde não há tecido suficiente para aproximar ou lesões grandes onde não é possível o fechamento com suturas (GOLDSTEINS; HESS, 1976; GREINER; LISKA; WITHROW, 1975; PODKONJAK, 1982; SCOTT; MILLER; GRIFFIN, 1995). Kuflik (1994) relata ainda a possibilidade de utilização da criocirurgia para o tratamento de tumores recidivantes, naquelas lesões próximas ou fixadas a ossos e cartilagens, considerando um método alternativo para pacientes nos quais outros métodos de tratamento são impraticáveis.

Das 57 formações submetidas ao tratamento de criocirurgia considerando-se os cães e gatos, a grande maioria 37 (64,91\%) localizavam-se em região da cabeça, 15 (26,31\%) em membros torácicos e/ou pélvicos e 5 (8,78\%) em região lombar. Na região da cabeça os principais locais acometidos eram o pavilhão auricular (22,80\%), o nariz $(17,54 \%)$ e a face (14,05\%). Formações nesses locais constituem um problema na cirurgia oncológica por serem locais que não dispõem de pele suficiente para possibilitar uma margem adequada e impossibilitam e/ou dificultam a utilização de técnicas de anaplastia. Tumores localizados em porção distal de membros, na maioria das vezes, acabam tendo como única opção de tratamento a amputação. Portanto, a criocirurgia possibilitou o tratamento de formações nesses locais sem maiores complicações e evitou a um primeiro momento a amputação de membros.

O desenvolvimento do câncer é um processo complexo no qual as células malignas proliferam para formar o tumor ou uma progênie de células transformadas. Todo esse processo envolve múltiplas alterações genéticas que resultam num processo maligno. O tumor cresce exponencialmente até alcançar um grama em tamanho, a partir daí o crescimento atinge um plateau onde células crescem e células morrem determinando o tamanho do tumor (MACEWEN; KHANNA; RADINSK, 2001). 
Em relação ao tempo de evolução das formações, observamos que a maioria dos animais apresentavam a formação por um período compreendido entre 2 meses e 1 ano de evolução. Esses valores refletem a pouca preocupação ou desinformação por parte do proprietário em relação ao surgimento de um nódulo em um animal. Na maioria das vezes a procura por tratamento ocorre quando estes se tornam maiores ou crescem rapidamente, onde em algumas situações já não se consegue fazer remoção seja pela característica infiltrativa do tumor ou o surgimento de metástases para outros órgãos.

Na literatura pesquisada alguns autores recomendam a utilização da criocirurgia com nitrogênio líquido no tratamento de lesões pequenas com até 2 centímetros de diâmetro (GRAHAM, 2001; YOUNG; SINCLAIR, 1997) enquanto outros preconizam que pode ser utilizada em lesões grandes (KRAHWINKEL, 1980; KUFLIK 1997). Nas lesões que apresentavam mais de um centímetro de diâmetro procedeu-se o congelamento dividindo a mesma em parte menores para que se obtivesse um melhor controle da área a ser congelada. Graham (2001) apesar de recomendar a utilização da criocirurgia em lesões com até 2 centímetros, aconselha que quando se utilizar em lesões maiores estas sejam divididas em partes menores.

As formações submetidas a criocirurgia apresentavam dimensões variadas, a grande maioria $(82,46 \%)$ apresentavam diâmetros menor ou igual a 3 centímetros, muito embora tenha sido utilizada em formações com até 11 centímetros com resultado satisfatório.

O diagnóstico das neoplasias de pele e/ou partes moles é imprescindível para que se estabeleça a terapia adequada, bem como termos um valor preditivo no prognóstico. Diversos autores como Dernell et al. (1998); Stone (1995); Vail e Withrow (2001) e Withrow (1998) relatam a importância da citologia no diagnóstico dessas afecções. No nosso trabalho realizamos a citologia em 28 dos 40 animais, nos demais por diferentes motivos não foi possível realizá-la. Dos 28 espécimes examinados 15 apresentaram correlação com o 
diagnóstico histopatológico demonstrando assim que a eficiência da citologia em relação ao exame histopatológico foi de 53,57\% diferindo dos resultados encontrados por Chalita et al. (2001) e Vasconcelos (2002) que obtiveram uma sensibilidade da citologia de 89\% e 87,5\% respectivamente. A diferença dos resultados em relação aos encontrados por esses autores pode ter ocorrido por falha na obtenção de amostra representativa ou no preparo do esfregaço.

Levando-se em consideração aos resultados obtidos por meio do exame histopatológico o carcinoma de células escamosas foi o quadro mórbido mais freqüente dentre os tumores tratados pela criocirurgia nos felinos. Dentre os caninos, o mais freqüente foi o tumor maligno de nervo periférico em seguida o adenoma sebáceo. Resultados esses semelhantes aos obtidos por Lucas (1998) em relação aos felinos, no entanto diferem quanto aos cães onde os mais freqüentes foram o adenoma sebáceo seguido pelo carcinoma de células escamosas quando utilizou a criocirurgia em dermatoses de caninos e felinos.

Dentre as formações submetidas ao tratamento de criocirurgia 3 (6\%) não caracterizavam processo neoplásico ao resultado do exame histopatológico, apesar do aspecto clínico semelhante a neoplasia tratavam-se de um processo cicatricial, uma dermatite crônica hiperplásica e uma displasia fibroanexial, constituindo-se dessa forma lesões pseudoneoplásicas que são descritas por Henderson e Brewer (1993).

O tempo de congelamento variou de 15 a 60 segundos, este tempo foi definido com base no tamanho da formação, quadro mórbido e localização. Durante o congelamento procuramos ser criteriosos, pois, a destruição tecidual ocorre de forma não seletiva e pode lesionar estruturas vitais adjacentes a lesão onde se deseja tratar, sendo assim o tempo de congelamento aplicado foi sendo ajustado conforme experiências anteriores.

A maioria, 25 (43,86\%) formações foram submetidas a 30 segundos de congelamento, resultado condizente aos relatados pelos autores consultados que referem um 
tempo de congelamento de 30 a 60 segundos ou até que sensores térmicos acusem uma temperatura $-50^{\circ} \mathrm{C}$. Tempo cirúrgico este extremamente rápido quando comparado a excisão cirúrgica que segundo Bojrab (1978); Goldestein e Hess (1977); Greiner; Liska; Withrow (1975); Lane (1974a); Lucas (1998); Podkonjak (1982); Withrow (1975) e Withrow (1989) é uma vantagem da criocirurgia, além do baixo custo e a segurança. O tempo de descongelamento não foi mensurado porque não traz nenhuma modificação em relação a terapia em si, o descongelamento total foi mensurado por meio de palpação digital e desaparecimento do halo de gelo, embora alguns autores façam referência a este tempo algo em torno de 3 à 5 minutos.

A maioria das formações $(80,7 \%)$ foram submetidas a dois ciclos de congelamento-descongelamento enquanto que 11 (19,3\%) a três ciclos de congelamento. No experimento de Lucas (1998) foi realizado 1 ciclo em 2\% dos cães, 2 ciclos em $70 \%$ e 3 ciclos em $28 \%$ entre os felinos estes valores foram 4,5\%, 64,2\% e 31,3\% respectivamente. Em nenhum momento utilizou-se um único ciclo de congelamento porque já está bem estabelecido que destruição celular é diretamente proporcional ao número de ciclos de congelamento-descongelamento. Sendo assim, durante um procedimento de criocirurgia via de regra deve-se congelar o tecido alvo pelo menos duas vezes (BOJRAB, 1978). Autores como Kuflik (1994); Thai e Sinclair (1999) e Zouboulis (1999) ressaltam que repetidos ciclos de congelamento-descongelamento asseguram o máximo dos efeitos destrutivos em tumores cutâneos. Em estudos com auxílio da microscopia eletrônica em pele normal observou-se que a destruição de todas as estruturas das células ocorria após o segundo ciclo de congelamentodescongelamento. Zacarian (1994) recomendava um duplo ciclo de congelamentodescongelamento para todos os tipos de tumores malignos de pele.

Cinco (12,5\%) animais dentre os caninos e felinos já haviam sido submetidos a outras formas de terapia sem sucesso, incluindo a criocirurgia em 2 animais, excisão cirúrgica 
em 2 e um animal havia sido tratado com quimioterapia. No trabalho desenvolvido por Lucas (1998) 56\% dos felinos e 28\% dos caninos também haviam sido submetidos a outros tipos de terapias.

Kuflik (1994) e Zouboulis (1998) em relatos a respeito da criocirurgia na medicina fazem referência a repetição do tratamento quando os resultados não forem suficientes na primeira aplicação podendo ser repetido depois de 20 à 30 dias da primeira sessão. Durante o procedimento de criocirurgia precisa-se ter cautela, algumas lesões localizam-se em locais de difícil realização do procedimento e o escape de nitrogênio líquido pode comprometer estruturas próximas ou vizinha da área a ser congelada. Dessa forma em alguns casos uma única sessão pode não ser suficiente para resolução do quadro. Clarke (1991) tratando carcinomas de células escamosas em felinos obteve resolução de 9\% das lesões após a segunda sessão de congelamento e $2 \%$ após a terceira. No nosso trabalho, 5 $(12,5 \%)$ animais foram submetidos a mais de uma sessão porque suas formações localizavamse próximo a olho, narina, em lábio que são locais onde deve-se preservar ao máximo, evitando assim possíveis seqüelas.

A cicatrização das formações submetidas ao procedimento de criocirurgia ocorreu por segunda intenção tendo em vista que este procedimento provoca morte celular e consequentemente necrose tecidual. O tempo de cicatrização está diretamente relacionado com as dimensões da lesão, tempo e temperatura de congelamento os quais induzirão a uma maior ou menor ferida e o manejo da ferida. No nosso trabalho, esse tempo variou de 15 à 120 dias, sendo que a maioria das feridas (60\%) cicatrizaram entre 21 à 60. Uma boa evolução cicatricial requer um manejo adequado da ferida por meio de lavagem, aplicação de pomadas cicatrizantes e curativos diários. Entretanto, esses cuidados era realizado pelos proprietários e fugia ao nosso controle. Sendo assim, feridas com dimensões semelhantes levaram tempos diferentes para que ocorresse a cicatrização completa. Muito embora tenha ocorrido 
interferências desses fatores extrínsecos, nossos resultados não fogem aos resultados encontrados por outros autores, pois, Graham (2001); Kuflik (1997) e Zacarian (1994), afirmam que lesões na face, pálpebras, nariz, orelha e pescoço geralmente cicatrizam entre 4 à 6 semanas, enquanto que tumores grandes localizados no tronco e extremidades cicatrizam por volta de 14 semanas.

No que se refere a eficácia do tratamento de um modo geral podemos observar que houve uma taxa de $80 \%$ de cura dos animais considerando-se a remissão total da lesão. Levando-se em consideração ao número de lesões, ou seja, processos neoplásicos (53) obtivemos 83\% de remissão total. Resultados esses próximos aos encontrados por Lucas (1998), que obtiveram cerca de 90 e $70 \%$ de cura dos caninos e felinos tratados pela criocirurgia respectivamente, levando em consideração que este autor utlizou a criocirurgia em dermatoses de caninos e felinos, incluindo formações neoplásicas e não neoplásicas, nossos resultados provavelmente ultrapassaram os obtidos por este autor. Por outro lado são semelhantes aos resultados encontrados por Clarke (1991), utilizando a criocirurgia como modalidade de tratamento cirúrgico de carcinoma de células escamosas em felinos, das 163 lesões que foram tratadas com a criocirurgia, ocorreu remissão total em 85 (83\%). Em estudo incluindo criocirurgia como método de tratamento para carcinomas de células escamosas do plano nasal de 61 felinos, Lana et al. (1997) utilizaram a criocirurgia com nitrogênio líquido em 11 casos e destes, 8 (73\%) recidivaram no mesmo local em um tempo médio de 184 dias.

Utilizando a criocirurgia no tratamento de tumores e fístulas, em cães, Goloubeff e Oliveira (1999) observaram regressão completa em três casos de adenoma hepatóide de glândula perianal, dois casos de fístulas da glândula adanal, quatro casos de tumor venéreo transmissível, um caso de hiperplasia epitelial pseudo carcinomatosa, dois casos de complexo de fístulas glandulares adanais e perianais e um caso de papilomatose oral. 
A taxa de cura da criocirurgia desde o ano de 1981 quando utilizada em carcinomas basocelular e espinocelular de humanos tem sido em torno de $98 \%$ nos estudo desenvolvidos por Graham e Zacarian (1993). Estes autores referem que essa melhora na taxa de cura está relacionada a uma seleção apropriada do tumor, melhor afinidade com a técnica, seleção apropriada do número de congelamento, curetagem antes da criocirurgia, monitorização da profundidade de congelamento. Concordamos em todos os aspectos com estes autores, lembrando que a técnica de criocirurgia apesar de ser de fácil execução requer conhecimento necessário dos princípios e de sua aplicação. Embora não tenhamos monitorizado a temperatura e profundidade de congelamento, consideramos ser de grande importância, principalmente naquelas formações com suspeita de malignidade, onde requer uma maior profundidade e temperaturas menores de congelamento.

A literatura veterinária faz referência ao uso da criocirurgia em uma variedade de neoplasias de pele e/ou partes moles, entretanto, são poucos os trabalhos que enfocam o aspecto do tratamento quanto ao percentual de cura e resultados obtidos. Dentre as neoplasias de pele e/ou partes moles (BOJRAB, 1978; GOLDSTEIN; HESS, 1977; GREINER; LISKA; WITHROW, 1975; KRAHWINKEL, 1980; LANE, 1974a; LANE, 1974b; LEOPARD, 1975; LISKA, 1980 WITHROW, 1975; WITHROW, 2001) relatam a aplicação da criocirurgia no tratamento de adenoma e adenocarcinoma, carcinoma basocelular, espinocelular, fibroma, fibrossarcoma, hemangioma, hemangiossarcoma, histiocitoma, mastocitoma, tricoepitelioma.

Quanto ao aspecto do diagnóstico das lesões tratadas, a sua maioria eram carcinoma de células escamosas $(n=19)$, adenoma sebáceo $(n=12)$ e tumor maligno do nervo periférico (n=6) . Considerou-se como insucesso da terapia os casos de remissão parcial, remissão total com recidiva, os que não se conseguiu fazer o acompanhamento, consistiram em um tumor de revestimento de nervo periférico, um hemangiopericitoma, três carcinomas espinocelular, um fibrossarcoma, um plasmocitoma. 
Os autores Kuflik (1994); Thai e Sinclair (1999) e Young e Sinclair (1997) classificam as complicações associadas a criocirurgia como permanentes ou temporárias. Dentre as complicações temporárias as mais freqüentes são hemorragia, edema ou dor durante ou imediatamente o procedimento, já as permanentes incluem retração tecidual, neuropatia, ruptura de tendões, alopecia, hipopigmentação. No nosso trabalho, a maioria das complicações foram classificadas como temporárias, tendo sido observado edema em 7 (17,5\%) animais, claudicação em 4 (10\%), prurido em 3 (7,5\%), dor em 3 (7,5\%) e hemorragia em 1(2,5\%) animal. A complicação permanente mais comum foi alopecia, tendo sido observado em 30 (75\%) animais, seguida por 1 (2,5\%) caso de retração tecidual com consequente obstrução de narina em felino. Clarke (1991) utilizando a criocirurgia no tratamento de carcinomas em gatos obteve como principal complicação a obstrução de narina. A obstrução de narina pela cicatrização após procedimento de criocirurgia é citada na literatura como desvantagem do tratamento em carcinomas no plano nasal, porém, esta complicação pode ocorrer também durante o processo cicatricial após resseccção de carcinomas de plano nasal. As complicações ora referidas também foram observadas por Lucas (1998), porém em maior percentual, exceto para a alopecia, onde estes observaram em apenas $16 \%$ dos casos, e retração tecidual não foi observada por este autor.

Apesar de Fretz e Holmberg (1980) referirem edema nas primeiras 48 horas pós- congelamento, em nosso trabalho, o edema observado persistiu por um período de até 7 dias em 3 animais, acreditamos que essa persistência esteve relacionada não somente a ação do congelamento, bem como pela localização das lesões, todas em porção distal de membros e próximas a grandes vasos como a veia cefálica e safena lateral comprometendo de certa forma o retorno venoso.

Confrontando esses dados com relatos da literatura médica, Jaramillo-Ayerbe (2000) refere presença de edema por um período de até 10 dias e dor nas primeiras 12 à 48 
horas, Zacarian (1994) observou presença de edema duas semanas após criocirurgia no tratamento de carcinoma basoescamoso. Gonçalves (1997) relata como complicações mais comuns observadas após criocirurgia em carcinomas basocelular em região de pálpebras e periorbital um edema considerável, e discreta retração cicatricial. portanto, nossos resultados corroboram com os resultados desses autores.

Quanto ao acompanhamento dos 34 animais solicitamos o comparecimento do proprietário quando possível ou mantivemos contato por telefone para avaliar a evolução dos casos tratados. Esse tempo variou de 1 à 16 meses, período que correspondeu ao desenvolvimento desse trabalho. Observamos que nesse período houve a ocorrência de apenas duas recidivas e os demais (94,11\%) estão sob controle sem evidência de tumor.

Confrontando esses períodos de acompanhamento com os de outros autores, encontramos que Lucas (1998) obteve maior êxito quanto ao seguimento, de praticamente, $60 \%$ dos gatos e $28 \%$ dos cães tratados, durante um à seis meses. Autores como Krahwinkel (1976) e Clarke (1991) relatam tempos de seguimento dos casos de 24 à 87 meses.

Zacarian (1994) tratando carcinomas basoescamoso e espinocelular de humanos refere um período de acompanhamento de 7 à 5 anos respectivamente sem recidiva, Kuflik e Gage (1997) acompanharam pacientes tratados para carcinoma basocelular por um período de 1 à 10 anos e destes somente dois apresentaram recidiva após 3 e 7 anos. Gonçalves (1997) tratando o mesmo tipo de tumor refere período de acompanhamento de 5 anos sem recidiva.

Os resultados obtidos e os resultados dos diversos autores comprovam que a criocirurgia é um procedimento que possibilita o tratamento de tumores de pele e/ou partes moles, principalmente naqueles casos onde outras formas de tratamento seriam impossibilitadas. No entanto é necessário que novas pesquisas sejam realizadas a respeito do tema ora discutido com intuito de se verificar com melhor acurácia a eficácia da técnica, no 
tocante a monitorização da temperatura atingida no centro da lesão, bem como, lançar mão de exames que possam planejar melhor o tratamento e que tenham valor preditivo para o prognóstico dos casos tratados. 
CONCLUSÕES 


\section{CONCLUSÕES}

Diante dos resultados expostos podemos concluir que:

- A criocirurgia foi eficaz no tratamento de neoplasias de pele e/ou parte moles de cães e gatos.

- A eficácia da criocirurgia está relacionada ao tempo de congelamento/descongelamento bem como ao número de ciclos aplicados.

- A criocirurgia apresenta menores riscos ao paciente em relação às técnicas cirúrgicas radicais.

- Complicações decorrentes a criocirurgia podem ocorrer: alopecia, edema, claudicação, prurido, dor, hemorragia e estenose. 
REFERÊNCIAS 


\section{REFERÊNCIAS*}

ALMEIDA GONÇALVES, J. C. Fractional cryosurgery: a new technique for basal cell carcinoma of the eylids and periorbital area. Dermatology Surgery, v. 23, n. 6, p. 475-481, 1997.

ANTHONY, M. L. Surgical treatment of nonmelanoma skin cancer. AORN Journal, v. 71, n. 3, p. 552-570, 2000.

BAXTER, J. S. The machinery of veterinary cryosurgery. Journal of Small Animal Practice, v. 19, n. 1, p. 27-34, 1977.

BELLANGEON, M. Cryochirurgie dans le traitement des cancers - Encyclopédie Vétérinaire, Paris, 1999, Cancérologie 0900, 7 p.

BERNARDEAU, K.; DERANCOURT, C.; CAMBIE, M. P.; SALMON-EHR, V.; MOREL, M.; CAVENELLE, F.; LÉONARD, F.; KALIS, B.; BERNARD, P. Cryochirurgie des carcinomes basocellulaires: étude de 358 malades. Annal Dermatology Venereology, v. 127, n. 2, p. 175-179, 2000.

BOJRAB, M. J. Veterinary cryosurgery: an overview. Norden News, v. 53, p. 16-20, 1978.

BRYNE, M. D. Cryosurgical instrumentation. Veterinary Clinics of North America. Small Animal Practice, v. 10, n. 4, p. 771-777, 1980.

CHALITA, M. C. C. MATERA, J. M.; ALVES, M. T. S.; LONGATTO FILHO, A. Tumores em pele e partes moles de cães. Estudo clínico e cito-histológico. Revista de Educação Continuada do CRMV-SP, v. 5, n. 2, p.171-180, 2002.

CLARKE, R. E. Cryosurgical treatment of feline cutaneous squamous cell carcinoma. Australian Veterinary Practitioner, v. 21, n. 3, p.148-153, 1991.

COOPER, S. M.; DAWBER, R. P. R. The history of cryosurgery. Journal of the Royal Society of Medicine, v. 94, n. 4, p. 196-201, 2001.

DAWBER, R. Cryosurgery: unapproved uses, dosages, or indications. Clinics in Dermatology, v. 20, n. 5, p. 563-570, 2002.

DERNELL, W. S.; WITHROW, S. J.; KUNTZ, C. A.; POWERS, B. E. Principles of treatment for soft tissue sarcoma. Clinical Techniques in Small Animal Practice, v. 13, n. 1, p. 59-64, 1998.

DOBSON, J. M.; SAMUEL, S.; MILSTEIN, H.; ROGERS, K.; WOOD, J. L. N. Canine neoplasia in the UK: estimates of incidence rates from a population of insured dogs. Journal of Small Animal Practice, v. 43, n. 6, p. 240-246, 2002.

\footnotetext{
* Elaborada de acordo com as Diretrizes para apresentação de dissertações e teses na Faculdade de Medicina Veterinária e Zootecnia da Universidade de São Paulo. 4. ed. São Paulo, 2003.
} 
FAZIO, M.; AIROLDI, M.; CANARUTTO, P.; NEGRI, L. Crioimmunologia e tumori del cavo orale. Minerva Stomatologica, v. 32, n. 6, p. 783-789, 1983.

FAZIO, M.; AIROLDI, M.; MASTROMATTEO, V.; NEGRI, L.; GANDOLFO, S.;

FURLANI, D. Cryosurgery as a stimulator of the host's immune defences in benign and malignant oral cavity tumors. Panminerva Medicine, v. 24, n. 3, p. 195-201, 1982.

FERRIS, D. G.; HO, J. J. Cryosurgical equipament: a critical review. The Journal of Family Practice, v. 35, n. 2, p.185-193, 1992.

FRETZ, P. B.; HOLMBERG, D. L. Sequelae to cryosurgery. Veterinary Clinics of North America. Small Animal Practice, v. 10, n. 4, p. 869-875, 1980.

GAGE, A. A. Cryosurgery in the treatment of cancer. Surgery, Gynecology and Obstetrics, v. 174, p. 73-92, 1992.

GAGE, A. A., BAUST, J. G. Cryosurgery - a review of recent advances and current issues. Cryoletters, v. 23, n. 2, p. 69-78, 2002.

GAGE, A. A. Cryosurgery of advanced tumors. Clinics in Dermatology, v. 8, n. 1, p. 86-95, 1990.

GAZZANIGA, S.; BRAVO, A.; GOLDSZMID, S. R.; MASCHI, F.; MARTINELLI, J.; MORDOH, J.; WAINSTOK, R. Inflamatory changes after cryosurgery-induced necrosis in human melanoma xenografted in nude mice. The Journal of Investigation Dermatology, v. 116, n. 5, p. 664-671, 2001.

GILSON, S. D.; PAGE, R. L. Principles of oncology. In: BIRCHARD, S. J.; SCHERDING, R. G. Saunders manual of small animal practice. 2. ed. Philadelphia: W. B. Saunders, 2000 section 3, chapter 24, p. 197-204.

GOLDSCHMIDT, M. H.; SHOFER, F. S. Skin tumors of the dog and cat. Oxford: Pergamon Press, 1992. 316 p.

GOLDSTEIN, R. S.; HESS, P. W. Cryosurgery of canine and feline tumors. Journal of American Animal Hospital Association v. 12, p. 340-349, 1976.

GOLDSTEIN, R. S.; HESS, P. W. Cryosurgical treatment of cancer. Veterinary Clinics of North America. Small Animal Practice. v. 7, n. 1, p. 51-64, 1977.

GOLOUBEFF, B.; OLIVEIRA, H. P. Tratamento criocirúrgico de tumores e fístulas, em cães. Arquivo Brasileiro de Medicina Veterinária e Zootecnia, v. 51, n. 5, p. 463-469, 1999.

GOURLEY, I. M.; VASSEUR, P. B. General small animal surgery. Philadelphia: J. B. Lippincott , 1985. p. 929-939.

GRAHAM, G. F. Cryosurgery in the management of cutaneous malignancies. Clinics in Dermatology, v. 19, p. 321-327, 2001. 
GRAHAM, G. F. Advances in cryosurgery during the past decade. Cutis, v. 52, p. 365-372, 1993.

GRAHAM, J. C.; O’KEEFE, D. A. Soft tissue sarcomas and mast cell tumors. In: BIRCHARD, S. J.; SCHERDING, R. G. Saunders manual of small animal practice. 2. ed. Philadelphia: W. B. Saunders, 2000. section 3, chapter 26, p. 214-221.

GREINER, T. P.; LISKA, W. D.; WITHROW, S. J. Cryosurgery. Veterinary Clinics of North America. Small Animal Practice. v. 5, n. 3, p. 565-581, 1975.

HENDERSON, R. A.; BREWER, W. G. Skin and subcutis. In: SLATER, D. Text book of small animal surgery. 2. ed., Philadelphia: W. B. Saunders, 1993. p. 2075-2088.

HOFFMANN, N. E.; BISCHOF, J. C. Cryosurgery of normal and tumor tissue in the dorsal skin flap chambre: part. 1 - termal response. Journal of Biomechanical Engineering, v. 123, p. 301-309, 2001.

HOLDEN, H. B.; MCKELVIE, P. Cryosurgery in the treatment of head and neck neoplasia. British Journal Surgery, v. 59, n. 9, p. 709-712, 1972.

HOLMBERG, D. L. Cryosurgery. In: SLATER, D. Text book of small animal surgery. 2. ed. Philadelphia: W. B. Saunders, 1993. p. 191-196.

HONG, J. S.; RUBINSKY, B. Patterns of ice formation in normal and mallignant breast tissue. Cryobiology, v. 31, p. 109-120, 1994.

JARAMILLO-AYERBE, F. Cryosurgery in difficult to treat basal cell carcinoma. International Journal of Dermatology,. v. 39, p. 223-229, 2000.

KRAHWINKEL, D. J. Cryosurgical treatment of skin diseases. Veterinary Clinics of North America. Small Animal Practice, v. 10, n. 4, p. 787-801, 1980.

KUFLIK, E. G. Cryosurgery for cutaneous malinancy. Dermatology Surgery, v. 23, p. 10811087, 1997.

KUFLIK, E. G. Cryosurgery updated. Journal of the American Academy of Dermatology, v. 31, n. 6, p. 925-944, 1994.

KUFLIK, E. G.; GAGE, A. A. Recurrent basal cell carcinoma treated with cryosurgery. Journal of the American Academy of Dermatology, v. 37, n. 1, p. 82-84, 1997.

LANA, S. E.; OGILVIE, G. K.; WITHROW, S.J.; STRAW, R. C.; ROGERS, K. S. Feline cutaneous squamous cell carcinoma of the nasal planun and the pinnae: 61 cases. Journal of the American Animal Hospital Association, v. 33, n. 4, p. 329-332, 1997.

LANE, J. G. Practical cryosurgery - an introduction for small animal clinicians. Journal of Small Animal Practice, v. 15, n. 12, p. 715-725, 1974a.

LANE, J. G. The clinical applications of cryosurgery in small animal practice. The Veterinary Annual, v. 14, p. 216-219, 1974b. 
LEMOS JUNIOR, C. A. Criocirurgia em lesões benignas da mucosa bucal - revisão da literatura e sua avaliação clínica em 37 casos. 1999. 92 f. Dissertação (Mestrado em Odontologia) - Faculdade de Odontologia, Universidade de São Paulo, São Paulo, 1999.

LEOPARD, P. J. Cryosurgery , and it's application to oral surgery. British Journal Oral Surgery, v. 13, n. 2, p. 128-152, 1975.

LISKA, W. D. Anorectal and perianal cryosurgery. Veterinary Clinics of North America. Small Animal Practice, v. 10, n. 4, p. 803-820, 1980.

LUCAS, R. Crioterapia na clínica veterinária: avaliação da praticabilidade, exeqüibilidade e efetividade em dermatoses de caninos e felinos. 1998. $111 \mathrm{f}$. Dissertação (Mestrado em Medicina Veterinária) - Faculdade de Medicina Veterinária e Zootecnia, Universidade de São Paulo, São Paulo, 1998.

MACEWEN, E. G.; KHANNA, C.; RADINSKY, R. Cancer biology and metastasis. In: WITHROW, S. J.; MACEVEN, E. G. Small animal clinical oncology. 3. ed. Philadelphia: W. B. Saunders, 2001. p. 18-34.

MACEWEN, E. G.; POWERS, B. E.; MACY, D.; WITHROW, S. J. Soft tissue sarcomas. In: WITHROW, S. J.; MACEWEN, E. G. Small animal clinical oncology. 3. ed. Philadelphia: W. B. Saunders, 2001. p. 283-304.

MAIA, M.; RIBEIRO, A. E. Curso de criocirurgia. São Paulo: Centro de Estudos Dermatológicos Adolpho Carlos Linderberg - Clínica de Dermatologia da Santa Casa de São Paulo, 1997. 19 p. Apostila.

MAMEDE, R. C. M. Princípios gerais e técnicas de criocirurgia em cabeça e pescoço. In: BRANDÃO, L. G. ; FERRAZ, A. R. Cirurgia de cabeça e pescoço. São Paulo: Roca, 1989. p. 689.

MARCIANI, R. D.; TRODAHL, M. J. Postoperative sequelae of cryosurgery. Journal Oral Surgery, v. 33, n. 6, p. 458-461, 1975.

MENENDEZ, L. R.; TAN, M. S.; KIYABU, M. T.; CHAWLA, S. P. Cryosurgical ablation of soft tissue sarcomas. Cancer, v. 86, n. 1, p. 50-57, 1999.

NELL III, H. B. Imunotherapeutic effect of cryosurgical tumor necrosis. Veterinary Clinics of North America. Small Animal Practice, v. 10, n. 4, p. 763-769, 1980.

NESBITT, G. H. Canine cutaneous neoplastic and nonneoplastic tumors and cysts. In: NESBITT, G. H.; ACKERMAN, L. J. Canine and feline dermatology. Trenton: Veterinary Learning Systems, 1998. p. 279-313.

NESBITT, G. H. Feline cutaneous neoplastic and nonneoplastic tumors and cysts. In: NESBITT, G. H.; ACKERMAN, L. J. Canine and feline dermatology. Trenton: Veterinary Learning Systems, 1998. p. 451-470. 
PETERSON, J. L.; COUTO, C. G. Tumors of the skin and subcutaneous tissues. In:

BIRCHARD, S. J.; SCHERDING, R. G. Saunders manual of small animal practice. 2. ed., Philadelphia: W. B. Saunders, 2000. section 3, chapter 28, p. 226-234.

PIMENTEL, E. R. A. Controle histológico pelo método micrográfico de mohs em carcinoma basocelular tratado pela criocirurgia com nitrogênio líquido. 168 f.1997. Tese (Doutorado em Medicina) - Faculdade de Medicina, Universidade de São Paulo, São Paulo, 1997.

PODKONJAK, K. R. Veterinary cryotherapy - 1, a comprehensive look at uses, principles and success. Veterinary Medicine Small Animal Clinician, v. 77, p. 51-64, 1982.

POWER, B. E. The pathology of neoplasia. In: WITHROW, S. J.; MACEVEN, E. G. Small animal clinical oncology. 3. ed. Philadelphia: W. B. Saunders, 2001. p. 4-17.

SEIM III, H. B. Mechanisms of cold-induced celular death. Veterinary Clinics of North America. Small Animal Practice, v. 10, n. 4, p. 755-762, 1980.

SCOTT, D. W.; MILLER JR., W. H. GRIFFIN, C. G. Muller \& Kirk's small animal dermatology. Philadelphia: W. B. Saunders, 1995. 1213 p.

STONE, E. A. Biopsy: principles, technical considerations and pitfalls. Veterinary Clinics of North America. Small Animal Practice, v. 25, n. 1 p. 33-45, 1995.

STOCKFLETH, E.; STERRY, W. New modalities for basal cell carcinoma. Recent Results in Cancer Research, v. 160, p. 259-268, 2002.

THAI, K. E.; SINCLAIR, R. D. Cryosurgery of benign skin lesions. Australasian Journal of Dermatology, v. 40, p. 175-186, 1999.

VAIL, D. M.; WITHROW, S. J. Tumours of the skin and subcutaneous tissues. In: WITHROW, S. J.; MACEWEN, E. G. Small animal clinical oncology. 3. ed. Philadelphia: W. B. Saunders, 2001. p. 233-260.

VASCONCELLOS, C. H. C. Avaliação clínica de retalhos cutâneos fixados com sutura convencional ou sutura mais adesivo de cianocrilato na cirurgia reconsturtora em cães. 2002. 118 f. Tese (Doutorado em Medicina Veterinária) - Faculdade de Medicina Veterinária e Zootecnia, Universidade de São Paulo, São Paulo, 2002.

WHITTAKER, D. K. Mechanisms of tissue destruction following cryosurgery. Annals of the Royal College of Surgeons of England, v. 66, p. 313-318, 1984.

WITHROW, S. J. General principles of cryosurgical technique. Veterinary Clinics of North America. Small Animal Practice, v. 10, n. 4, p. 779-786, 1980.

WITHROW, S. J. Cryosurgery of canine and feline tumors . Journal of the American Animal Hospital Association, v. 11, p. 271-282, 1975.

WITHROW, S. J. Soft tissue sarcomas. The Veterinary Quarterly, v. 20, p. 16-17, 1998. Suplement 1. 
WITHROW, S. J. Why worry about cancer in pets?. In: WITHROW, S. J.; MACEWEN, E. G. small animal clinical oncology. 3. ed. Philadelphia: W. B. Saunders, 2001. p. 1-3.

YOUNG, R.; SINCLAIR, R. Practical cryosurgery. Australasian Family Physician, v. 26, n. 9, p. 1045-1047, 1997.

ZACARIAN, S. A. Cryosurgery in the management of cutaneous disorders and malignant tumours of the skin. Comprehensive Therapy, v. 20, n. 7, p. 379-401, 1994.

ZOUBOULIS, C. C. Cryosurgery in dermatology. European Journal of Dermatology, v. 8, n. 7, p. 466-474, 1998.

ZOUBOULIS, C. C. Principles of cutaneous cryosurgery: an update. Dermatology, v. 198, p. 111-117, 1999. 
APÊNDICES 


\section{APÊNDICE A}

\begin{tabular}{|c|c|c|c|c|c|c|c|}
\hline $\begin{array}{l}\text { ANIMAL } \\
\text { № }\end{array}$ & SEXO & $\begin{array}{l}\text { IDADE } \\
\text { (anos) }\end{array}$ & ESPÉCIE & RAÇA & LOCALIZAÇÃO & CITOLOGIA & HISTOPATOLOGIA \\
\hline 01 & $\mathrm{M}$ & 9 & Canina & Cocker Spaniel & $\begin{array}{l}\text { Plano nasal } \\
\text { Mentoniano }\end{array}$ & Inconclusiva & $\begin{array}{l}\text { Epitelioma de Meibômio } \\
\text { Fibroma }\end{array}$ \\
\hline 02 & $\mathrm{~F}$ & 21 & Felina & SRD & Cabeça & Sarcoma & Hemangiosarcoma \\
\hline 03 & $\mathrm{M}$ & 6 & Canina & Poodle & Cabeça & Inconclusiva & Adenoma Sebáceo \\
\hline 04 & $\mathrm{~F}$ & 11 & Canina & Cocker Spaniel & Orelha esquerda & $\begin{array}{l}\text { Adenoma/ } \\
\text { Epitelioma }\end{array}$ & Epitelioma Sebáceo \\
\hline 05 & $\mathrm{M}$ & 12 & Canina & Cocker Spaniel Inglês & Plano nasal & Adenocarcinoma & Adenoma Sebáceo \\
\hline 06 & M & 8 & Canina & Bull Terrier & Paraprepucial & Carcinoma & Carcinoma Células Escamosas \\
\hline 07 & $\mathrm{~F}$ & 13 & Canina & SRD & Dorsolombar & Sarcoma & $\begin{array}{l}\text { Tumor Maligno de Revestimento de Nervo } \\
\text { Periférico }\end{array}$ \\
\hline 08 & $\mathrm{~F}$ & 12 & Canina & SRD & Orelha direita & Inconclusiva & Plasmocitoma Cutâneo \\
\hline 09 & $\mathrm{M}$ & 12 & Canina & Old English Sheepdog & Plano nasal & Inconclusiva & Tecido Cicatricial \\
\hline 10 & $\mathrm{M}$ & 10 & Canina & Pastor Belga & Dorsolombar & $\begin{array}{c}\text { Carcinoma } \\
\text { Processo inflamatório }\end{array}$ & Carcinoma Basoescamoso \\
\hline 11 & $\mathrm{~F}$ & 1 & Felina & SRD & $\begin{array}{c}\text { Orelhas } \\
\text { Plano Nasal }\end{array}$ & Inconclusiva & Carcinoma Celulas Escamosa \\
\hline 12 & F & 6 & Canina & Beagle & Cabeça & Carcinoma basocelular & Tricoblastoma Trabecular \\
\hline 13 & $\mathrm{~F}$ & 12 & Canina & SRD & Metacarpo MPE & Sarcoma & Fibrossarcoma \\
\hline 14 & $\mathrm{M}$ & 13 & Canina & Pastor Alemão & $\begin{array}{l}\text { Coxim Plantar } \\
\text { MTD }\end{array}$ & $\begin{array}{l}\text { Neoplasia mesenquimal } \\
\text { bem diferenciada }\end{array}$ & Displasia Fibroanexial \\
\hline 15 & F & 4 & Canina & SRD & $\begin{array}{l}\text { Coxim Plantar } \\
\text { MPD }\end{array}$ & Não Realizada & Dermatite Crônica Hiperplásica \\
\hline
\end{tabular}

Quadro 1 - Resultado epidemiológico, clínico, cito e histológico dos animais submetidos a criocirurgia no período de janeiro de 2003 a maio de 2004 no Serviço de Cirurgia de Pequenos Animais do Hospital Veterinário da Faculdade de Medicina Veterinária e Zootecnia da Universidade de São Paulo. São Paulo, 2004 


\begin{tabular}{|c|c|c|c|c|c|c|c|}
\hline 16 & $\mathrm{M}$ & 13 & Canina & Fox Paulistinha & $\begin{array}{l}\text { MTD - Região de } \\
\text { Rádio e Ulna }\end{array}$ & Sarcoma bem diferenciado & $\begin{array}{c}\text { Tumor Maligno de Revestimento de Nervo } \\
\text { Periférico } \\
\end{array}$ \\
\hline 17 & $\mathrm{~F}$ & 8 & Canina & Boxer & Coxa-MPD & Sarcoma & Hemangiopericitoma \\
\hline 18 & $\mathrm{~F}$ & 11 & Felina & SRD & Cabeça & Contaminação sangüínea & Carcinoma Espinocelular \\
\hline 19 & $\mathrm{M}$ & 13 & Canina & Labrador & Coxa - MPD & Sarcoma & Neurofibroma \\
\hline 20 & $\mathrm{M}$ & 13 & Canina & Boxer & $\begin{array}{c}\text { MTD - Região de Rádio } \\
\text { e Ulna }\end{array}$ & Sarcoma & $\begin{array}{c}\text { Tumor Maligno de Revestimento de Nervo } \\
\text { Periférico }\end{array}$ \\
\hline 21 & $\mathrm{M}$ & 9 & Canina & Fox Paulistinha & Cabeça, MTD & Não realizada & Adenoma Sebáceo \\
\hline 22 & $\mathrm{M}$ & 10 & Felina & SRD & Orelhas e Plano Nasal & Não realizada & Carcinoma Espinocelular \\
\hline 23 & $\mathrm{~F}$ & 12 & Felina & SRD & Narina Esquerda & Não realizada & Carcinoma Espinocelular \\
\hline 24 & $\mathrm{~F}$ & 10 & Felina & SRD & Nariz e Lábio Superior & Não realizada & Carcinoma Espinocelular \\
\hline 25 & $\mathrm{~F}$ & 10 & Felina & SRD & Nariz e Lábio Superior & Não realizada & Carcinoma Espinocelular \\
\hline 26 & $\mathrm{~F}$ & 8 & Felina & SRD & Orelhas e Plano Nasal & Não realizada & Carcinoma Espinocelular \\
\hline 27 & $\mathrm{M}$ & 12 & Felina & SRD & Plano Nasal & Não realizada & Carcinoma Espinocelular \\
\hline 28 & $\mathrm{M}$ & 13 & Felina & SRD & Nariz & Não realizada & Hemangiosarcoma \\
\hline 29 & $\mathrm{M}$ & 11 & Felina & SRD & Periocular & Carcinoma & Melanoma Amelanico \\
\hline 30 & $\mathrm{M}$ & 11 & Canina & Malamute do Alaska & Cabeça & Carcinoma & Epitelioma Sebáceo \\
\hline 31 & $\mathrm{~F}$ & 14 & Canina & SRD & $\begin{array}{c}\text { MTE - Região de Radio } \\
\text { e Ulna }\end{array}$ & Sarcoma & $\begin{array}{c}\text { Tumor Maligno de Revestimento de Nervo } \\
\text { Periférico }\end{array}$ \\
\hline 32 & $\mathrm{~F}$ & 9 & Canina & Poodle & Lombar & Não realizado & Adenoma Sebáceo \\
\hline 33 & $\mathrm{M}$ & 12 & Canina & Poodle & MPE, Fêmur & Sarcoma & $\begin{array}{c}\text { Tumor Benigno de Revestimento de Nervo } \\
\text { Periférico }\end{array}$ \\
\hline 34 & $\mathrm{M}$ & 7 & Canina & Pastor Alemão & Coxim Plantar & Contaminação sangüínea & Hemangioma \\
\hline 35 & $\mathrm{~F}$ & 6 & Canina & Boxer & $\begin{array}{l}\text { MPE - Região de Tíbia } \\
\text { e Fíbula }\end{array}$ & Sarcoma & $\begin{array}{c}\text { Tumor Maligno de Revestimento de Nervo } \\
\text { Periférico }\end{array}$ \\
\hline 36 & $\mathrm{~F}$ & 14 & Canina & Cocker Spaniel & Orelhas & Neoplasia epitelial benigna & Adenoma Sebáceo \\
\hline 37 & $\mathrm{M}$ & 7 & Canina & SRD & MTD, Metacarpo & Sarcoma & $\begin{array}{c}\text { Tumor Maligno de Revestimento de Nervo } \\
\text { Periférico } \\
\end{array}$ \\
\hline 38 & $\mathrm{~F}$ & 14 & Canina & Cocker Spaneil & MTD, Face dorsal mão & Neoplasia epitelial benigna & Epitelioma Sebáceo \\
\hline 39 & $\mathrm{M}$ & 5 & Felina & SRD & Orelha & Não realizado & Carcinoma Espinocelular \\
\hline 40 & $\mathrm{~F}$ & 6 & Felina & SRD & Orelha & Não realizado & Carcinoma Espinocelular \\
\hline
\end{tabular}

Quadro 1 - Resultado epidemiológico, clínico, cito e histológico dos animais submetidos a criocirurgia no período de janeiro de 2003 a maio de 2004 no Serviço de Cirurgia de Pequenos Animais do Hospital Veterinário da Faculdade de Medicina Veterinária e Zootecnia da Universidade de São Paulo. São Paulo, 2004 


\begin{tabular}{|c|c|c|c|}
\hline $\begin{array}{l}\text { ANIMAL } \\
\text { № }\end{array}$ & DIAGNÓSTICO & $\begin{array}{c}\text { ACOMPANHAMENTO } \\
\text { (meses) }\end{array}$ & CATEGORIA \\
\hline 01 & Adenoma e Epitelioma de Meibômio & 16 & RT \\
\hline 02 & Hemangiossarcoma & 7 & RT \\
\hline 03 & Adenoma Sebáceo & 15 & RT \\
\hline 04 & Epitelioma Sebáceo & 14 & RT \\
\hline 05 & Adenoma Sebáceo & 14 & RT \\
\hline 06 & Carcinoma de Células Escamosas & - & - \\
\hline 07 & Tumor Maligno de Nervo Periférico & 7 & $\mathrm{RT} / \mathrm{R}$ \\
\hline 08 & Plasmocitoma & - & - \\
\hline 09 & Processo Cicatricial & 14 & RT \\
\hline 10 & Carcinoma Basoescamoso & 13 & RT \\
\hline 11 & Carcinoma de Células Escamosas & - & - \\
\hline 12 & Tricoblastoma Trabecular & 13 & RT \\
\hline 13 & Fibrossarcoma & - & - \\
\hline 14 & Displasia Fibroanexial & 12 & RT \\
\hline 15 & Dermatite Crônica Hiperplásica & 12 & RT \\
\hline 16 & Tumor Maligno de Nervo Periférico & 6 & RT \\
\hline 17 & Hemangiopericitoma & - & - \\
\hline 18 & Carcinoma de Células Escamosas & 11 & RT \\
\hline 19 & Tumor Benigno de Nervo Periférico & 6 & RT \\
\hline 20 & Tumor Maligno de Nervo Periférico & 11 & RT \\
\hline 21 & Adenoma Sebáceo & 14 & RT \\
\hline 22 & Carcinoma de Células Escamosas & 7 & RT \\
\hline 23 & Carcinoma de Células Escamosas & 5 & RT \\
\hline 24 & Carcinoma de Células Escamosas & 4 & RT \\
\hline 25 & Carcinoma de Células Escamosas & 6 & RT \\
\hline 26 & Carcinoma de Células Escamosas & 6 & RT \\
\hline 27 & Inconclusivo & 4 & RT \\
\hline 28 & Hemangiossarcoma & - & - \\
\hline 29 & Melanoma Amelânico & 8 & RT \\
\hline 30 & Epitelioma Sebáceo, Adenoma Sebáceo & 8 & RT \\
\hline 31 & Tumor Maligno do Nervo Periférico & 6 & RT \\
\hline 32 & Adenoma Sebáceo & 6 & RT \\
\hline 33 & Tumor Benigno de Nervo Periférico & 7 & RT \\
\hline 34 & Hemangioma & 9 & RT \\
\hline 35 & Tumor Maligno de Nervo Periférico & 11 & RT \\
\hline 36 & Adenoma Sebáceo & 1 & RT \\
\hline 37 & Tumor Maligno de Nervo Periférico & 6 & RT \\
\hline 38 & Epitelioma Sebáceo & 3 & RT \\
\hline 39 & Carcinoma de Células Escamosas & 2 & RT \\
\hline 40 & Carcinoma de Células Escamosas & 1 & RT \\
\hline
\end{tabular}

Quadro 2 - Animais tratados pela criocirurgia, distribuição quanto ao tempo de acompanhamento e avaliação dos resultados. Serviço de Cirurgia de Pequenos Animais do HOVET FMVZ/USP (janeiro de 2003 a maio de 2004). São Paulo, 2004 


\section{APÊNDICE B}

Tabela 1 - Freqüência dos cães e gatos submetidos a criocirurgia, quanto a distribuição racial. Serviço de Cirurgia de Pequenos Animais do HOVET - FMVZ/USP (janeiro de 2003 a maio de 2004). São Paulo, 2004

\begin{tabular}{clcc}
\hline \multirow{2}{*}{ ESPÉCIE RAÇA } & \multicolumn{2}{c}{ FREQÜÊNCIA } \\
\cline { 3 - 4 } & & $\mathbf{N} \mathbf{0}$ & $\mathbf{\%}$ \\
\hline \multirow{5}{*}{ Canina } & 6 & 22,23 \\
& CRD & 5 & 18,53 \\
& Bocker Spaniel & 3 & 11,11 \\
& Poodle & 3 & 11,11 \\
& Fox Paulistinha & 2 & 7,40 \\
& Pastor Alemão & 2 & 7,40 \\
& Beagle & 1 & 3,70 \\
& Bull Terrier & 1 & 3,70 \\
& Labrador & 1 & 3,70 \\
& Malamute do Alaska & 1 & 3,70 \\
& Old English Sheep Dog & 1 & 3,70 \\
& Pastor Belga & 1 & 3,70 \\
\hline Felina & SRD & 13 & 100 \\
\hline & TOTAL & $\mathbf{4 0}$ & $\mathbf{1 0 0}$ \\
\hline
\end{tabular}

Tabela 2 - Distribuição das 57 lesões dos cães e gatos $(n=40)$ submetidos a criocirurgia quanto a localização. Serviço de Cirurgia de Pequenos Animais do HOVET - FMVZ/USP (janeiro de 2003 a maio de 2004). São Paulo, 2004

\begin{tabular}{clcc}
\hline \multirow{2}{*}{ REGIÃO } & \multirow{2}{*}{ LOCALIZAÇÃO } & \multicolumn{2}{c}{ FREQÜÊNCIA } \\
\cline { 3 - 4 } & Pavilhão auricular & 13 & $\mathbf{\%}$ \\
\hline \multirow{3}{*}{ Cabeça } & 8 & 22,80 \\
& Face & 10 & 14,05 \\
& Nariz & 1 & 17,54 \\
& Lábio & 1 & 1,75 \\
& Mento & 4 & 1,75 \\
& Periocular & 4 & 7,02 \\
\hline \multirow{2}{*}{ Membros } & Fêmur & 1 & 7,02 \\
& Tíbia e fíbula & 4 & 1,75 \\
& Rádio e ulna & 2 & 7,02 \\
& Metacarpos & 3 & 3,51 \\
& Coxim Plantar & 1 & 5,27 \\
& Face dorsal da mão & 4 & 1,75 \\
\hline \multirow{2}{*}{ Abdômen } & Lateral & 1 & 7,02 \\
& Paraprepucial & $\mathbf{5 7}$ & 1,75 \\
\hline \multirow{2}{*}{ TOTAL } & & $\mathbf{1 0 0}$ \\
\hline
\end{tabular}


Tabela 3 - Freqüência dos cães e gatos submetidos a criocirurgia em relação aos tempo de evolução das lesões. Serviço de Cirurgia de Pequenos Animais do HOVET - FMVZ/USP (janeiro de 2003 a maio de 2004). São Paulo, 2004

\begin{tabular}{|c|c|c|}
\hline \multirow{2}{*}{$\begin{array}{c}\text { TEMPO DE EVOLUÇÃO } \\
\text { (dias) }\end{array}$} & \multicolumn{2}{|c|}{ FREQÜÊENCIA } \\
\hline & № & $\%$ \\
\hline 07 & 1 & 2,5 \\
\hline 10 & 1 & 2,5 \\
\hline 30 & 2 & 5 \\
\hline 60 & 7 & 17,5 \\
\hline 90 & 2 & 5 \\
\hline 120 & 4 & 10 \\
\hline 150 & 1 & 2,5 \\
\hline 180 & 6 & 15 \\
\hline 210 & 1 & 2,5 \\
\hline 240 & 1 & 2,5 \\
\hline 365 & 5 & 12,5 \\
\hline 730 & 3 & 7,5 \\
\hline Não informado & 6 & 15 \\
\hline TOTAL & 40 & 100 \\
\hline
\end{tabular}

Tabela 4 - Freqüência das lesões dos cães e gatos submetidos a criocirurgia em relação aos diâmetros. Serviço de Cirurgia de Pequenos Animais do HOVET - FMVZ/USP (janeiro de 2003 a maio de 2004). São Paulo, 2004

\begin{tabular}{|c|c|c|}
\hline \multirow{2}{*}{ DIÂMETRO EM CM } & \multicolumn{2}{|c|}{ FREQÜÊNCIA } \\
\hline & № & $\%$ \\
\hline$<1$ & 20 & 35,09 \\
\hline$\geq 1 \mathrm{e}<3$ & 27 & 47,37 \\
\hline$\geq 3 e<5$ & 5 & 8,77 \\
\hline$\geq 5 \mathrm{e}<7$ & 2 & 3,51 \\
\hline$\geq 7 \mathrm{e}<9$ & 2 & 3,51 \\
\hline$\geq 9 \mathrm{e}=11$ & 1 & 1,75 \\
\hline TOTAL & 57 & 100 \\
\hline
\end{tabular}


Tabela 5 - Freqüência das formações dos cães e gatos submetidos a criocirurgia, distribuição quanto ao resultado do histopatológico. Serviço de Cirurgia de Pequenos Animais do HOVET FMVZ/USP (janeiro de 2003 a maio de 2004). São Paulo, 2004

\begin{tabular}{|c|c|c|c|c|c|}
\hline \multirow{2}{*}{\multicolumn{3}{|c|}{ CARACTERIZAÇÃO }} & \multirow{3}{*}{$\begin{array}{r}\text { TIPO } \\
\text { Adenoma Sebáceo }\end{array}$} & \multicolumn{2}{|c|}{ FREQÜÊNCIA } \\
\hline & & & & № & $\%$ \\
\hline \multirow{15}{*}{ 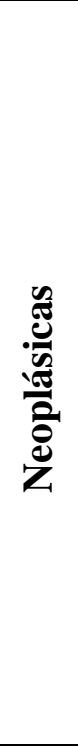 } & \multirow{7}{*}{ } & \multirow{4}{*}{ Benignas } & & 12 & 21,05 \\
\hline & & & Epitelioma Sebáceo & 3 & 5,27 \\
\hline & & & Epitelioma de Meibômio & 1 & 1,75 \\
\hline & & & Tricoblastoma & 1 & 1,75 \\
\hline & & \multirow{3}{*}{ Malignas } & Carcinoma Células Escamosas & 19 & 33,35 \\
\hline & & & Carcinoma Basoescamoso & 1 & 1,75 \\
\hline & & & Plasmocitoma Cutâneo & 1 & 1,75 \\
\hline & \multirow{8}{*}{ 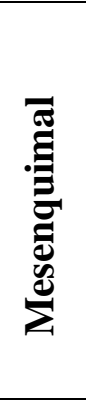 } & \multirow{3}{*}{ Benignas } & Fibroma & 1 & 1,75 \\
\hline & & & Hemangioma & 1 & 1,75 \\
\hline & & & Tumor de Nervo Periférico & 2 & 3,52 \\
\hline & & \multirow{5}{*}{ Malignas } & Fibrossarcoma & 1 & 1,75 \\
\hline & & & Hemangiopericitoma & 1 & 1,75 \\
\hline & & & Hemangiossarcoma & 2 & 3,52 \\
\hline & & & Melanoma Amelânico & 1 & 1,75 \\
\hline & & & Tumor de Nervo Periférico & 6 & 10,54 \\
\hline \multirow{3}{*}{\multicolumn{3}{|c|}{ Não neoplásicas }} & Dermatite Crônica Hiperplásica & 1 & 1,75 \\
\hline & & & Displasia Fibroanexial & 1 & 1,75 \\
\hline & & & Processo Cicatricial & 1 & 1,75 \\
\hline \multicolumn{3}{|c|}{ Não caracterizada } & & 1 & 1,75 \\
\hline \multicolumn{3}{|c|}{ TOTAL } & & 57 & 100 \\
\hline
\end{tabular}

